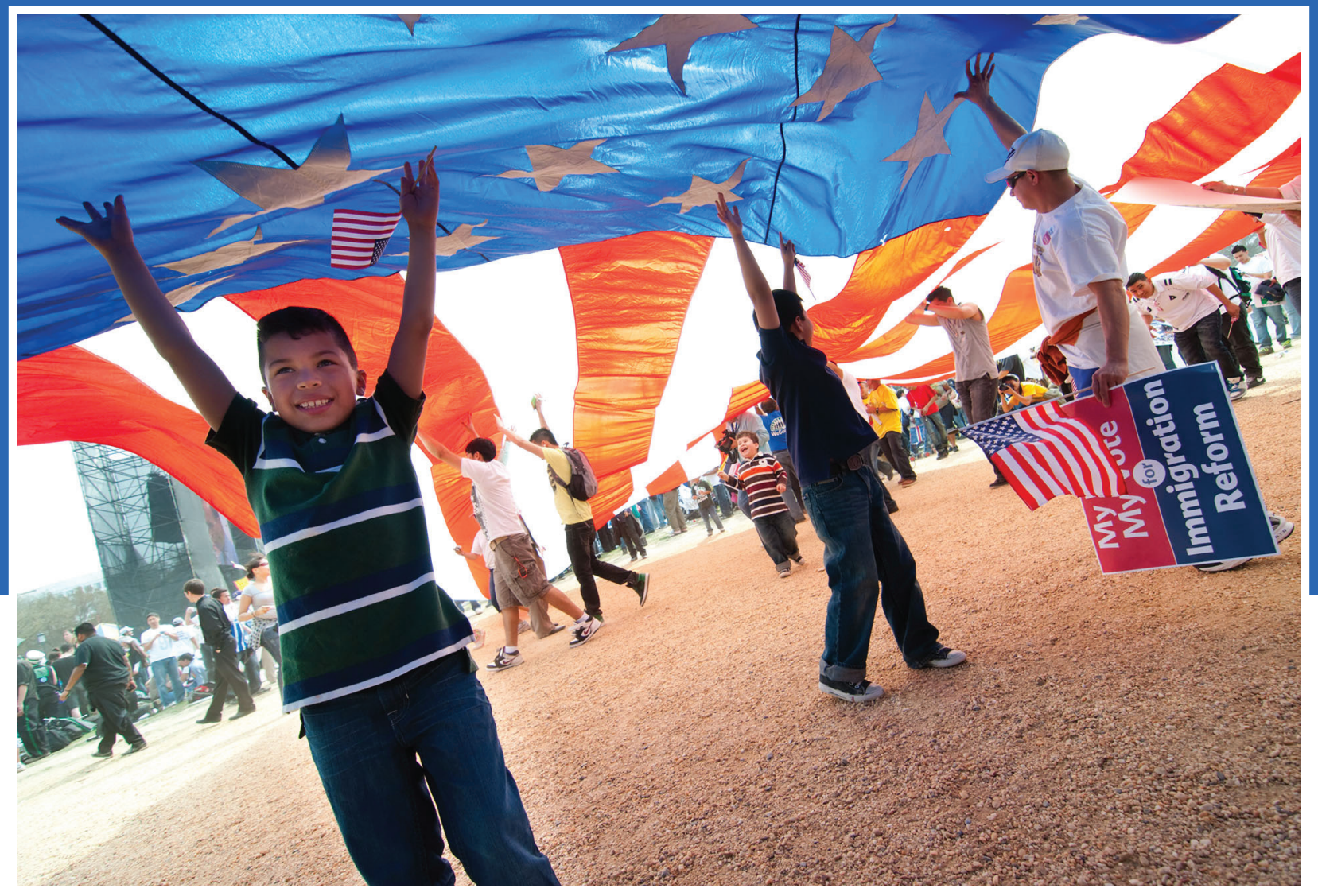

Making Citizenship an Organizing Principle of the US Immigration System:

An Analysis of How and Why to Broaden Access to Permanent Residence and Naturalization for New Americans

By Donald Kerwin, Robert Warren, and Charles Wheeler

June 2021

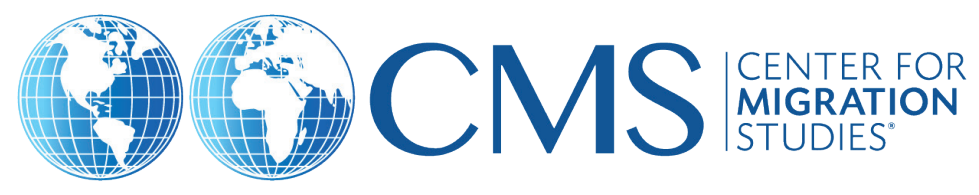


Suggested Citation: Kerwin, Donald, Robert Warren, and Charles Wheeler. 2021. Making Citizenship an Organizing Principle of the US Immigration System: An Analysis of How and Why to Broaden Access to Permanent Residence and Naturalization for New Americans. Center for Migration Studies of New York (CMS) Report. New York, NY: CMS.

(C) 2021 Center for Migration Studies of New York (CMS). All Rights Reserved.

No part of this publication may be reproduced or transmitted in any form by any means, electronic or print, including photocopy, or any information storage retrieval system, without the permission of CMS.

For more information, visit www.cmsny.org

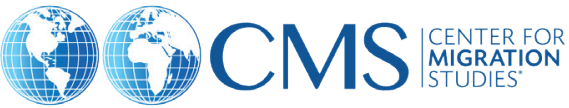




\section{Photos}

Cover: Editorial credit: Ryan Rodrick Beiler / Shutterstock.com

1. Editorial credit: Joseph Sohm / Shutterstock

2. Father/Son - Editorial credit: Ryan Rodrick Beiler / Shutterstock

3. Editorial Credit: Jonathan Weiss / Shutterstock

4. Credit: Moab Republic / Shutterstock

5. Credit: AJR_photo/Shutterstock

6. Credit: Elias Castillo/Unsplash 


\section{Table of Contents}

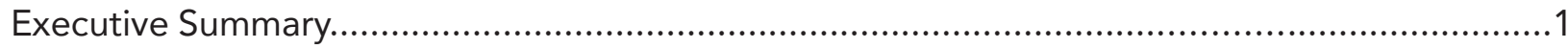

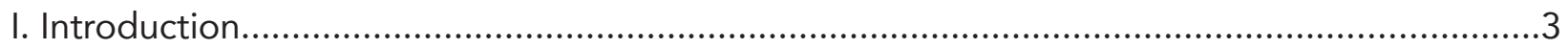

II. Removing Barriers to Permanent Residence and Naturalization......................................9

Steps Taken by Biden-Harris Administration to Expand Access to

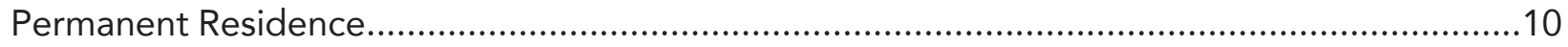

Public Charge Grounds of Inadmissibility.........................................................10

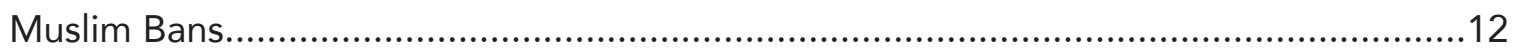

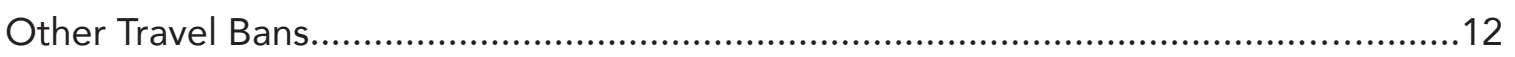

Temporary Protected Status and Other Humanitarian Relief..................................13

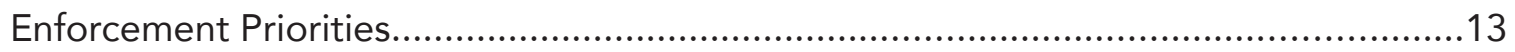

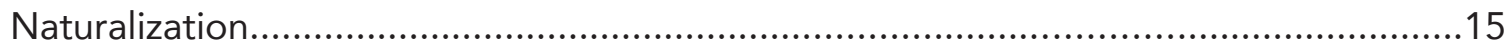

Steps the Biden-Harris Administration Should Take to

Expand Access to Permanent Residence.................................................................... 16

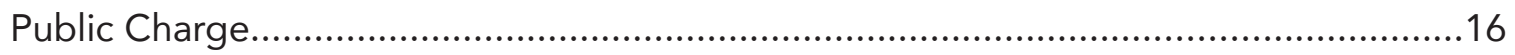

Deferred Action for Childhood Arrivals..................................................................16

Other Humanitarian Relief....................................................................... 17

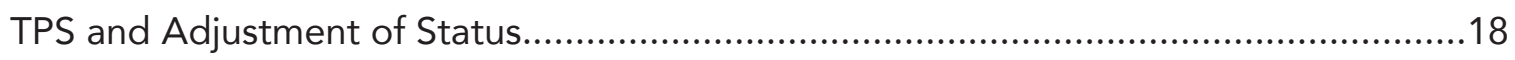

Extreme Vetting and Backlogs......................................................................

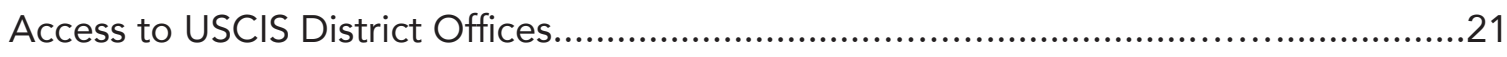

III. Naturalization Determinants and Naturalization Rates by State,

Metropolitan Area, and Country of Birth..........................................................22

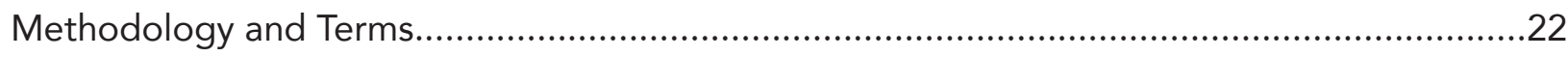

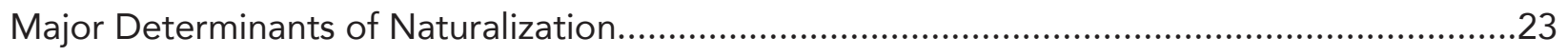

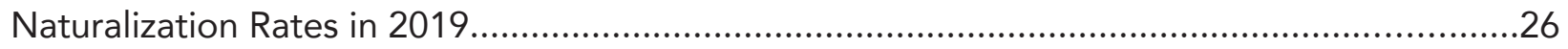

Changes in Naturalization Rates for Selected Countries from 2010 to 2019.........................33

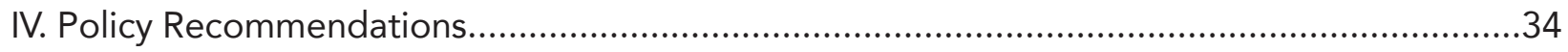

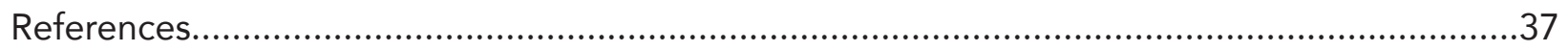




\title{
Making Citizenship an Organizing Principle of the US Immigration System: An Analysis of How and Why to Broaden Access to Permanent Residence and Naturalization for New Americans
}

\author{
By Donald Kerwin, Robert Warren, and Charles Wheeler
}

\section{Executive Summary}

This paper proposes that the United States treat naturalization not as the culmination of a long and uncertain individual process, but as an organizing principle of the US immigration system and its expectation for new Americans. It comes at a historic inflection point, following the chaotic departure of one of the most nativist administrations in US history and in the early months of a new administration whose executive orders, administrative actions, and legislative proposals augur an entirely different view of immigrants and immigration.

The paper examines two main ways that the Biden-Harris administration's immigration agenda can be realized - by expanding access to permanent residence and by increasing naturalization numbers and rates. First, it proposes administrative and, to a lesser degree, legislative measures that would expand the pool of eligible-to-naturalize immigrants. Second, it identifies three underlying factors - financial resources, English language proficiency, and education - that strongly influence naturalization rates. It argues that these factors must be addressed, in large part, outside of and prior to the naturalization process. In addition, it provides detailed estimates of populations with large eligible-to-naturalize numbers, populations that naturalize at low rates, and populations with increasing naturalization rates. It argues that the administration's immigration strategy should prioritize all three groups for naturalization.

The paper endorses the provisions of the US Citizenship Act that would place undocumented and temporary residents on a path to permanent residence and citizenship, would reduce family- and employment-based visa backlogs, and would eliminate disincentives and barriers to permanent residence. It supports the Biden-Harris administration's early executive actions and proposes additional measures to increase access to permanent residence and naturalization. It also endorses and seeks to inform the administration's plan to improve and expedite the naturalization process and to promote naturalization.

The paper's major findings regarding the eligible-to-naturalize population include the following:

- In 2019, about 74 percent, or 23.1 million, of the 31.2 million immigrants (that were eligible for naturalization) had naturalized.

- Three states - Indiana, Arizona, and Texas - had naturalization rates of 67 percent, well below the national average of 74 percent.

- Fresno, California had the lowest naturalization rate (58 percent) of the 25 metropolitan (metro) areas with the largest eligible-to-naturalize populations, followed by Phoenix at 66 percent and San Antonio and Austin at 67 percent. 
- Four cities in California had rates of 52 to 58 percent - Salinas, Bakersfield, Fresno, and Santa Maria-Santa Barbara.

- McAllen, Laredo, and Brownsville had the lowest naturalization rates in Texas.

- Immigrants from Japan had the lowest naturalization rate (47 percent) by country of origin, followed by four countries in the 60 to 63 percent range - Mexico, Canada, Honduras, and the United Kingdom.

- Guatemala and El Salvador each had rates of 67 percent.

- Median household income was $\$ 25,800$, or 27 percent, higher for the naturalized population, compared to the population that had not naturalized (after an average of 23 years in the US).

- In the past 10 years, naturalization rates for China and India have fallen, and rates for Mexico and Central America have increased (keeping duration of residence constant).

In short, the paper provides a roadmap of policy measures to expand the eligible-to-naturalize population, and the factors and populations that the Biden-Harris administration should prioritize to increase naturalization rates, as prerequisite to the full integration and participation of immigrants, their families, and their descendants in the nation's life. 


\section{Introduction}

Since his inauguration, President Biden has articulated a vision of immigrants and immigration through executive orders (EOs), administrative actions, and legislative goals that is sharply at odds with his predecessor's (CMS 2021). In his first day in office, the President issued a "Proclamation on Ending Discriminatory Bans on Entry to the United States," which states that the United States was "built on a foundation of religious freedom and tolerance, a principle enshrined in the United States Constitution." 1 The proclamation criticizes the previous administration's bans on entry of persons "from primarily Muslim countries" and "largely African countries" as a "stain on our national conscience" and an affront to the United States' "long history of welcoming people of all faiths and no faith at all." 2

In his second full week in office, President Biden issued an EO that articulates the economic and other contributions of immigrants to the nation's life. Titled "Restoring Faith in Our Legal Immigration Systems and Strengthening Integration and Inclusion Efforts for New Americans," the order states:

New Americans and their children fuel our economy, working in every industry, including healthcare, construction, caregiving, manufacturing, service, and agriculture. They open and successfully run businesses at high rates, creating jobs for millions, and they contribute to our arts, culture, and government, providing new traditions, customs, and viewpoints. They are essential workers helping to keep our economy afloat and providing important services to Americans during a global pandemic. They have helped the United States lead the world in science, technology, and innovation. And they are on the frontlines of research to develop coronavirus disease 2019 (COVID-19) vaccines and treatments for those afflicted with the deadly disease. ${ }^{3}$

The EO stresses the need to "encourage full participation by immigrants, including refugees, in our civic life; that immigration processes and other benefits are delivered effectively and efficiently; and that the Federal Government eliminates sources of fear and other barriers that prevent immigrants from accessing government services available to them. ${ }^{4}$ It also avers that the federal government "should develop welcoming strategies that promote integration, inclusion, and citizenship, and it should embrace the full participation of the newest Americans in our democracy." ${ }^{5}$ It directs an exhaustive review of "existing regulations, orders, guidance documents, policies, and any other similar agency actions" that are inconsistent with effective

1 "Proclamation on Ending Discriminatory Bans on Entry to the United States" Proclamation 10141, 86 Fed. Reg. 7005 (January 25, 2021).

2 Id.

3 "Restoring Faith in Our Legal Immigration Systems and Strengthening Integration and Inclusion Efforts for New Americans" Exec. Order No. 14012, 86 Fed. Reg. 8277 (February 2, 2021).

4 Id.

5 Id. 
and efficient delivery of "immigration processes and other benefits." ${ }^{6}$ It also calls for promoting "integration, inclusion, and citizenship."7 To that end, it requires the Secretary of State, Attorney General, and Secretary of Homeland Security to develop a plan to improve and expedite the naturalization process, ${ }^{8}$ which must consider ways to:

- Reduce naturalization processing times: processing times increased from 7.9 to 12.2 months between 2017 and March 31, 2021 (USCIS 2021a), contributing to a backlog of 744,693 cases of as June 30, 2020 (USCIS 2020).

- Increase the accessibility of naturalization via potential fee reductions and waivers.

- Facilitate naturalization for "eligible candidates born abroad and members of the military."

- Modify denaturalization and passport revocation policies so as "to ensure that these authorities are not used excessively or inappropriately."

The EO also established an Interagency Working Group on Promoting Naturalization "to develop a national strategy to promote naturalization." 10 In an early step toward promoting naturalization, the Biden-Harris administration abandoned the longer civics test adopted by US Citizenship and Immigration Services (USCIS) during the Trump administration, seeing it as a potential barrier to naturalization. ${ }^{11}$

The paper has four sections. The first sets forth the administration's immigration and naturalization agenda, places it in historical context, and argues that it reflects an open and inclusive vision of immigrants in the nation's life. The second describes ways the Biden-Harris administration can broaden access to permanent residence. The third analyzes three factors - financial resources, English language ability, and education - that influence the ability and willingness of immigrants to naturalize. It also provides estimated naturalization rates by selected national groups and by states and metro areas. It identifies populations with relatively low naturalization rates, populations with higher rates but still large numbers of eligible-to-naturalize persons, and populations with increasing naturalization rates. The fourth offers a series of policy proposals to place more immigrants on a path to permanent residence, naturalization, and integration into US society. The paper endorses, but does not elaborate on, the well-known legislative proposals to address barriers to naturalization, such as by reducing fees, expanding fee waivers,

6 Id.

7 Id.

8 The Obama administration similarly proposed a series of "federal strategic goals," to reduce barriers and increase access to naturalization (White House Task Force 2015a, 27-30).

9 "Restoring Faith in Our Legal Immigration Systems and Strengthening Integration and Inclusion Efforts for New Americans" Exec. Order No. 14012, 86 Fed. Reg. 8277 (February 2, 2021).

$10 \mathrm{Id}$.

11 US Citizenship and Immigration Services. 2021. "USCIS Reverts to the 2008 Version of the Naturalization Civics Test." Released February 22, 2021. https://www.uscis.gov/news/news-releases/uscis-reverts-to-the-2008-version-ofthe-naturalization-civics-test. 
expanding eligibility for waivers to the English language and civics requirements, and facilitating naturalization of members of the military.

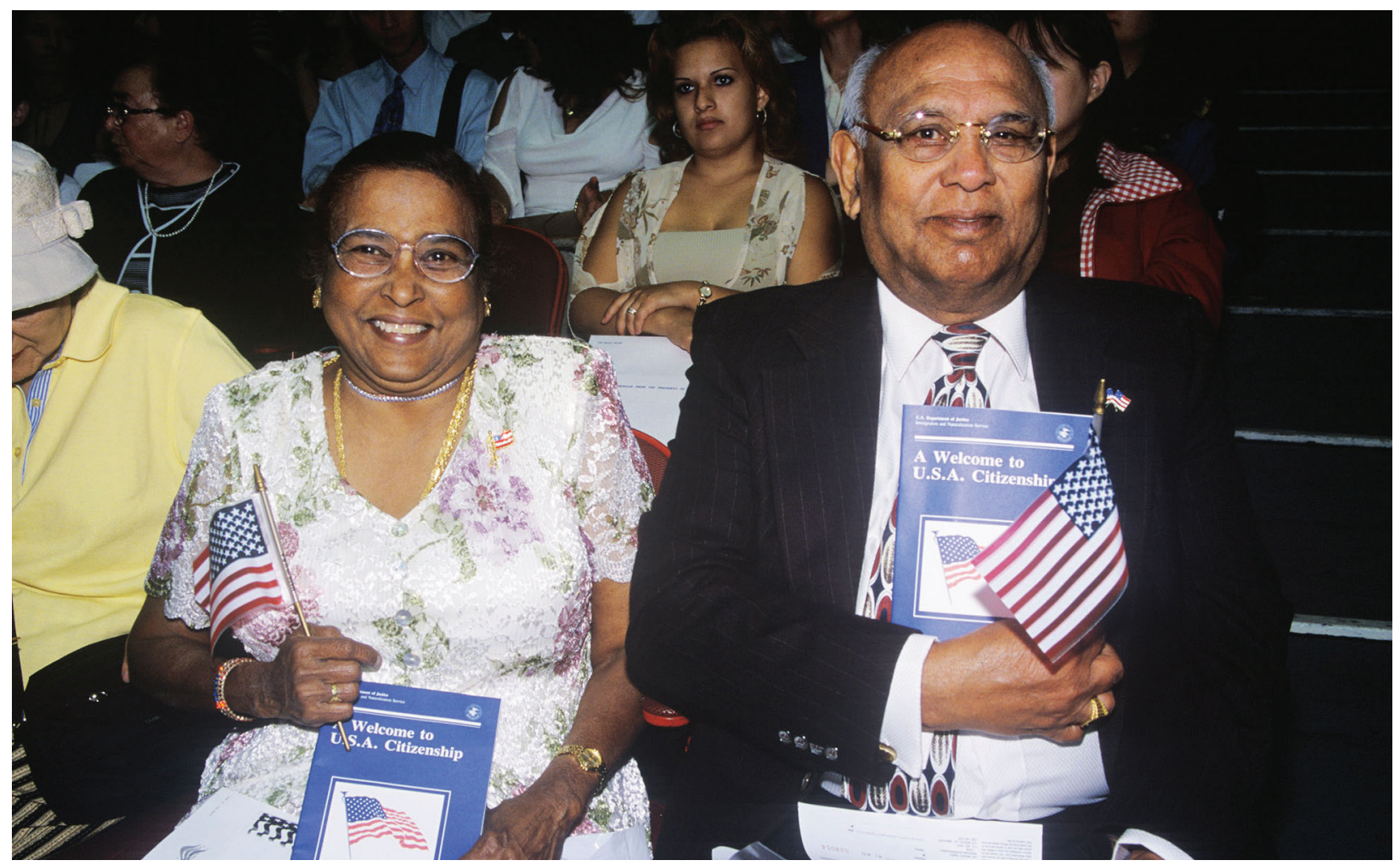

The Biden-Harris administration has raised the possibility of putting in place one of the most inclusive immigration and naturalization agendas in US history, with all the attendant economic, social, and cultural benefits to the nation. In a Nation of Immigrants, Susan Martin identified four immigration models in American history, dating to the early colonial era, which can help to contextualize BidenHarris immigration policies. These "colonial" models appear in different forms, places, and periods, and, to a degree, at the same time throughout US history. Moreover, they have been selectively applied to groups of favored and disfavored immigrants (Martin 2021, 110).

The Virginia model equated immigration with foreign-born laborers, to whom it extended limited rights (for indentured servants) or no rights (for slaves) and denied the possibility of full membership. This model appears in different forms throughout US history, particularly in the treatment of Chinese contract laborers who were later excluded under the Chinese Exclusion Acts, with the Bracero program's exploitation of Mexican farmworkers, and with the denial of public benefits to immigrants today.

The Massachusetts model welcomed immigrants based on shared religious convictions and values, but excluded, expelled, and persecuted others. This model can later be found in a positive form in the admission of refugees from communist regimes during the Cold War and in a negative form in grounds of exclusion based on religion and ideology (Wheeler 2014, 84).

The Pennsylvania model supports equal rights, religious and ethnic pluralism, diversity, and tolerance. It can be seen in the early years of the Americanization movement, a broadly-based initiative in the late $19^{\text {th }}$ and early $20^{\text {th }}$ centuries that sought to incorporate immigrants and 
make them US citizens. Martin argues that the country has benefited the most from immigration when it has adopted Pennsylvania model policies that promoted the rights and equality of immigrants and viewed them as "presumptive citizens" (Martin 2021, 357). Because this model permits immigrants to contribute fully to their new nation, it has the potential to positively transform the country, and to create "new Americans," both immigrants and US-born citizens (ibid., 383). The Obama administration also channeled the Pennsylvania model by recognizing immigrant integration as a "two-way process" that creates "shared" opportunities, benefits, and responsibilities between immigrants and "receiving communities" (White House Task Force 2015a, 3, 27-30).

As Martin points out, these first three models and their various expressions in US history all support at least some form of immigration, albeit for different reasons and on different conditions. By contrast, the fourth model, the "nativist" model, sees immigrants as un-American and a threat to the nation. As evidenced by the Trump administration, nativism is a recurrent feature of US history, and its rhetoric and strategies vary little from one era to another (Kraut 2016; Young 2017).

The Trump administration sought to reduce legal immigration by divesting certain legally present groups of status, instituting travel bans from select Muslim-majority and African countries, and creating new barriers to permanent residency and naturalization, particularly for low-income, working class persons and for family member of US citizens and lawful permanent residents (LPRs) (Guttentag 2021; Pierce and Bolter 2020; Kerwin and Warren 2019a). ${ }^{12}$ It also sought to dismantle US refugee resettlement and asylum programs (Schoenholtz, Ramji-Nogalez, and Schrag 2021; Martin 2020; Kerwin and Nicholson 2021). While it professed to favor the immigration of the wealthy and highly skilled, it made it more difficult for even these populations to enter (Anderson 2021 and 2020).

Immigrants make manifold economic, social, and cultural contributions to the nation, and these contributions increase as they advance in status to permanent residence and citizenship (Collins 2021; Kerwin and Warren 2019a; Lynch and Oakford 2013). ${ }^{13}$ Conversely, lack of immigration status negatively affects not just an immigrant's US citizen and LPR family members, but the integration of subsequent generations as well (NAS 2015, 124; Bean, Brown and Bachmeier

12 These barriers to permanent residence and naturalization included:

- A draconian new rule that expanded the public charge ground of inadmissibility.

- A proclamation that sought to condition adjustment of status on whether an immigrant has or could afford health insurance.

- High fee increases, and more limited and onerous fee waiver policies.

- Referral of those whose immigration applications were denied to removal proceedings.

- A range of punitive and costly investigation, vetting, and application processing and adjudication practices (Aleinikoff and Kerwin 2021, 7-10).

13 On average, for example, naturalized citizens equal or exceed the native-born population in education, employment, self-employment, work in skilled occupations, personal income, and homeownership (Kerwin and Warren 2019a, 3). 
2015, 185-86). ${ }^{14}$ Martin views the Trump presidency as an outlier, even for a nativist regime, in its sui generis rejection of the United States as a nation of immigrants and its many policies that must be revoked in order to reinstitute any of the three other models (Martin 2021, 355).

\section{"Immigrants make manifold economic, social and cultural contributions to the nation, and these contributions increase as they advance in status to permanent residence and citizenship."}

In Americans in Waiting, Hiroshi Motomura sought to resurrect the "lost story" of the nation's treatment of select immigrants as potential Americans. In particular, he examines the "declaration of intent" set forth in US naturalization laws from 1792 to 1952, which required immigrants to declare that they intended to naturalize in advance of being able to do so. This declaration, he argues, made them "intending citizens" (Motomura 2006, 116), triggering many of the benefits of citizenship such as voting rights in numerous states and territories, eligibility for land under The Homestead Act of 1862, and employment in many public jobs and public works projects (ibid., 117-19). In short, the declaration bespoke a transition to citizenship, which afforded immigrants citizen-like rights, privileges, and responsibilities. This model did not turn on equitable ties to the country or a contractual expectation that immigrants would be treated fairly or justly (but unequally) by their new country (ibid., 119). Motomura would treat lawful immigrants as would-be citizens, which (he argues) will encourage them to naturalize and afford them the best opportunity to "belong" and to integrate (ibid., 189-90). ${ }^{15}$

The Biden-Harris administration's early, immigration-related executive actions align most closely with the Pennsylvania model in celebrating the country's diversity, pluralism, and tolerance. The administration views immigration and refugee protection as consistent with US ideals and values. It refers to "new Americans," a term that may be more inclusive than even "intending" citizens or "Americans in waiting" as it implies that new immigrants are already Americans. ${ }^{16}$ It embraces undocumented immigrants, as reflected in its support for an immense general legalization program and several population-specific legalization programs. ${ }^{17}$ This paper seeks to contribute to implementation of the Biden-Harris administration's immigration agenda by proposing ways to broaden access to permanent residence and by identifying eligible-to-naturalize populations that should naturalize at higher rates and numbers.

14 The Trump administration's failure to reduce legal immigration significantly prior to the COVID-19 pandemic (Nowrasteh 2021; Chishti and Bolter 2020), can be attributed to the legal overreach of its administrative actions, many of which were temporarily enjoined or permanently blocked in federal court. The Biden-Harris administration has since reversed many of these policies.

15 For a proposal to build a robust, national integration policy infrastructure, see de Graauw and Bloemraad (2017).

16 "Restoring Faith in Our Legal Immigration Systems and Strengthening Integration and Inclusion Efforts for New Americans" Exec. Order No. 14012, 86 Fed. Reg. 8277 (February 2, 2021).

17 The Obama administration used the term "new Americans" as well and urged local communities to commit to the integration of "all" their residents. At the same time, President Obama enunciated a standard - "that everyone willing to work hard and play by the rules is welcome" - that would presumably exclude certain immigrants (White House Task Force on New Americans 2015b). 


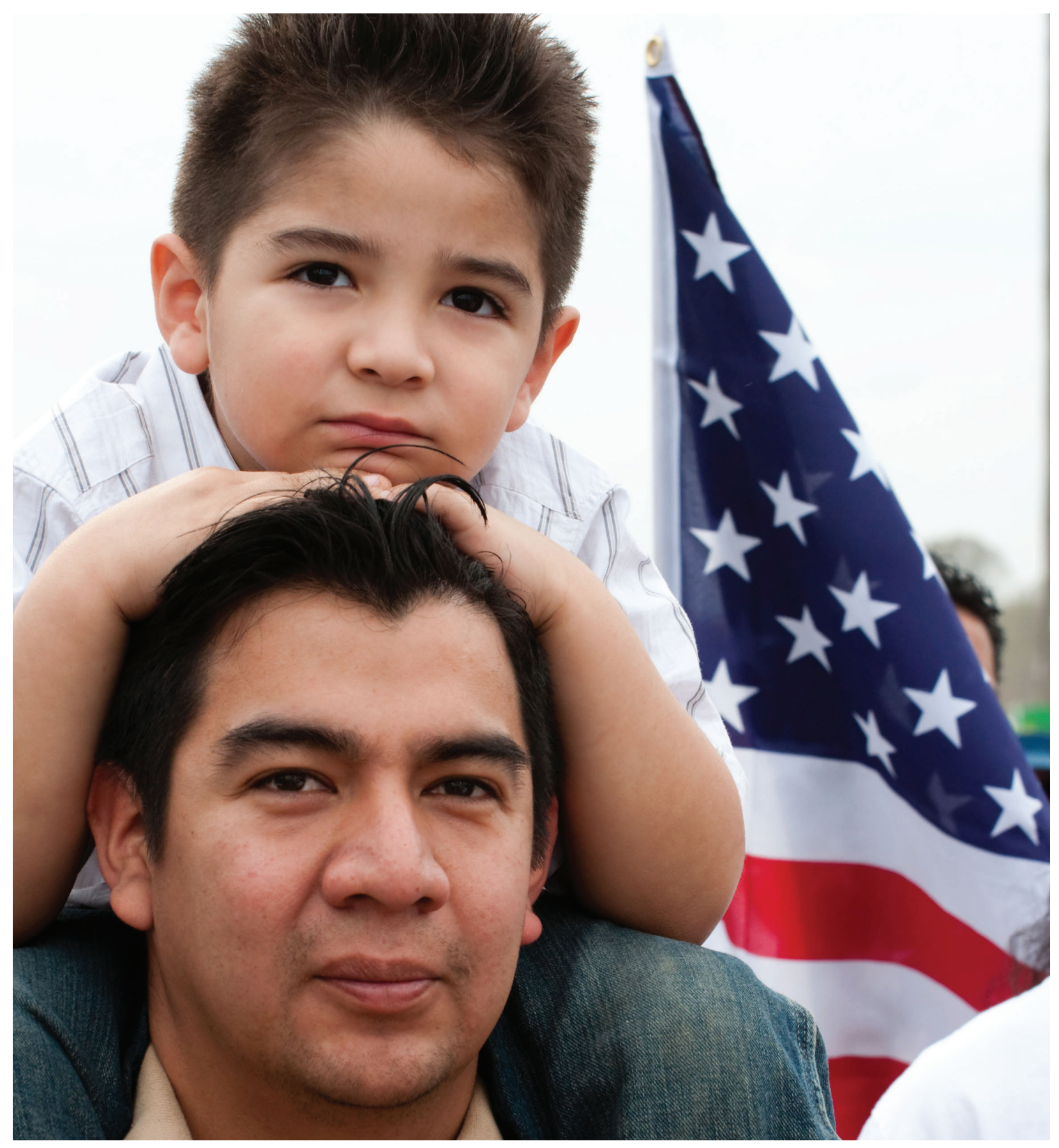

The Biden-Harris vision is starkly at odds with the Trump administration's nativist policies, which still resonate with large numbers of Americans. Yet the new administration has been measured in the speed with which it is moving in the direction of the Pennsylvania model. At this writing, for example, it has retained the Trump administration's order, justified on public health grounds, that allows the United States to expel asylum-seekers at its borders without any meaningful process. ${ }^{18}$

18 Centers for Disease Control and Prevention. "Orders Suspending Introduction of Certain Persons from Countries Where a Communicable Disease Exists" 85 Fed. Reg. 16567 (March 24, 2020). US Department of Health and Human Services. "Amendment and Extension of Order Suspending Introduction of Certain Persons from Countries Where a Communicable Disease Exists" (May 19, 2020). 


\section{Removing Barriers to Permanent Residence and Naturalization}

This section describes select administrative actions that the Biden-Harris administration has taken, and several more it should take, to put more US residents on a path to permanent residence, naturalization, and full incorporation in the nation's life.

While this section focuses on actual and proposed administrative actions, the Biden-Harris administration also supports broad legislative reform, including the US Citizenship Act of 2021. ${ }^{19}$ This Act would create the largest general legalization program in US history, as well as targeted legalization programs for Deferred Action for Childhood Arrivals (DACA) recipients, agricultural workers, essential critical infrastructure workers, Temporary Protected Status (TPS) and Deferred Enforced Departure (DED) recipients, and the permanent LGBTQ partners of US citizens and lawful permanent residents (LPRs). ${ }^{20}$ It would also reduce family- and employment-based visa backlogs - of 3.76 million and 215,600 (respectively) as of November 1, 2020 - by recapturing unused visas (DOS 2020). ${ }^{21}$ In addition, it would eliminate the three- and 10-year bars to admission based on unlawful presence, removing a disincentive for intending immigrants to leave the country for consular processing when their visas become available. In short, it would put millions of US residents on a path to permanent residence and naturalization.

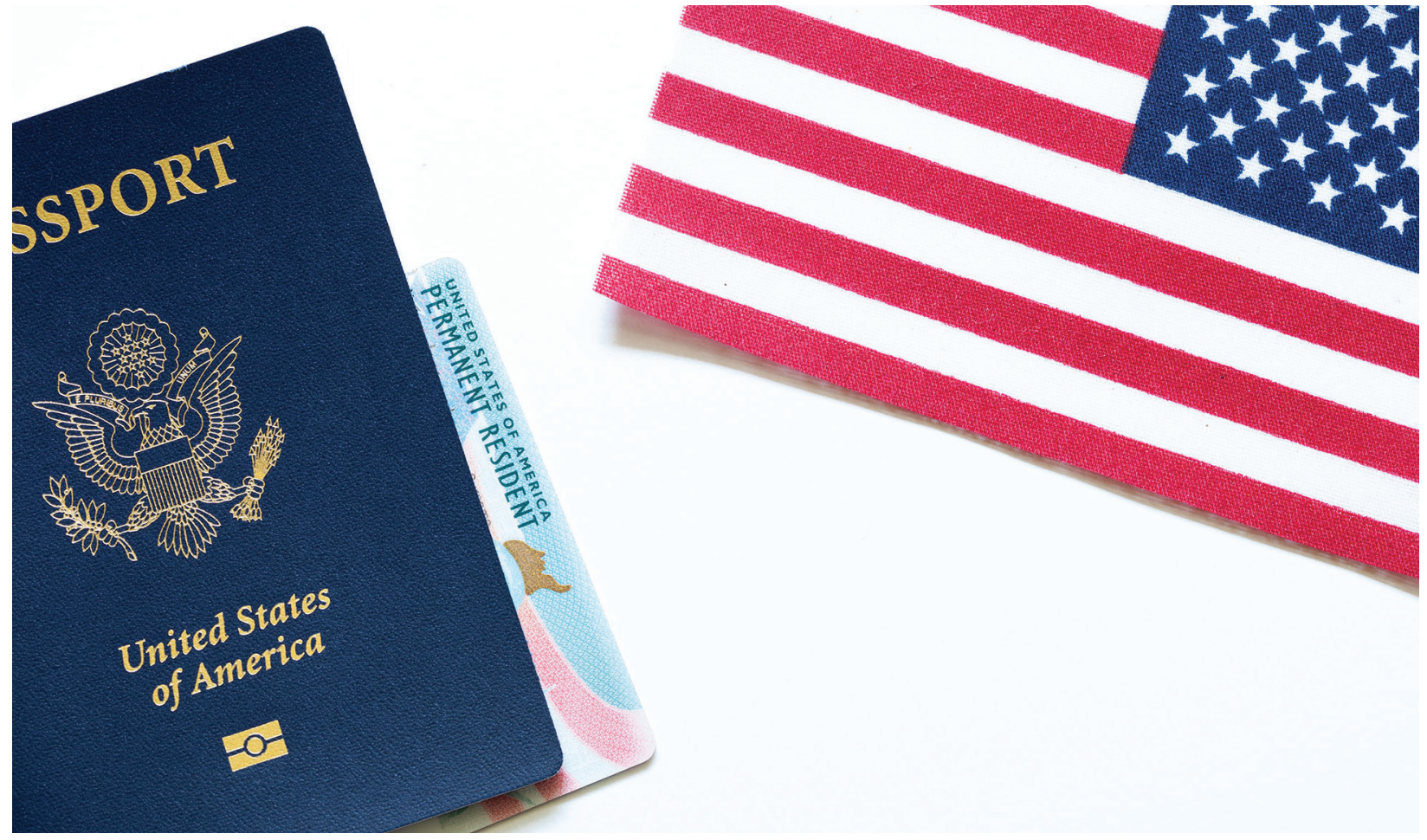

19 US Citizenship Act of 2021. H.R. 1177 and S. 348, 117 th Cong. (2021).

20 For a taxonomy and historical review of US legalization programs, see Kerwin (2010).

21 For an explanation of the causes and consequences of visa backlogs, which can last decades depending on the country of the intending immigrant and the family-based preference category, see Wheeler (2019) and Kerwin and Warren (2019b). 


\section{Steps Taken by Biden-Harris Administration to Expand Access to Permanent Residence}

\section{Public Charge Grounds of Inadmissibility}

US Department of State (DOS) officials "at the time of application for a visa" and US Department of Homeland Security (DHS) officials "at the time of application for admission or adjustment of status" must determine whether a noncitizen is likely to become a public charge. By statute, these officials must minimally consider - as part of a totality of the circumstances test - the noncitizen's age, health, family status, assets, resources and financial status, and education and skills. ${ }^{22}$ On August 14, 2019, DHS published a new rule on the public charge ground of inadmissibility, ${ }^{23}$ and it began to implement this rule on February 20, 2020. Its architects viewed the rule as a way to block "hundreds of thousands" of immigrants from gaining permanent residence (Miroff and Dawsey 2019).

Under the rule, USCIS officers would consider receipt of cash benefits in making public charge determinations and, in a change from the past, would also consider non-cash medical, housing, and food benefits. The rule also set forth a series of factors, weighted in favor of finding a large percentage of intending immigrants inadmissible. Even before it went into effect, the rule chilled the use of public benefits by immigrants and their US citizen and LPR family members (Bernstein et al. 2020).

On March 9, 2021, the Department of Justice (DOJ) dismissed its appeal of a Northern District of Illinois order ${ }^{24}$ that had vacated the 2019 public charge rule. ${ }^{25}$ On the same day, the US Court of Appeals for the Seventh Circuit lifted its stay of the order, and the vacatur went into effect halting all implementation and enforcement of the rule on a nationwide basis. The government also withdrew other appeals pending in the Ninth and Second Circuits, as well as the writ of certiorari that had been granted by the Supreme Court. Six days later, it formally removed the 2019 public charge rule from the Code of Federal Regulations effective March 9, 2021.26 At this writing, DHS is applying the public charge guidance set forth in the 1999 Interim Field Guidance, ${ }^{27}$ which requires that an applicant be "primarily dependent on the government for subsistence, as demonstrated by either (i) the receipt of public cash assistance for income

22 Immigration and Nationality Act (INA) § 212(a)(4).

2384 Fed. Reg. 41292 (August 14, 2019).

24 Cook County et al. v Wolf et al., No. 19 C 6334 (N.D. III. 2020).

2584 Fed. Reg. 41292 (August 14, 2019).

2686 Fed. Reg. 14221 (March 15, 2021).

2764 Fed. Reg. 24689 (March 26, 1999). 
maintenance or (ii) institutionalization for long-term care at government expense" (INS 1999). ${ }^{28}$

The DOS public charge rule, in turn, had been enjoined by a district court in New York since July 29, 2020, ${ }^{29}$ and the Form DS-5540, Public Charge Questionnaire, had been discontinued as of that date. The Biden-Harris administration withdrew its appeal of that district court decision. In response, the State Department updated its Foreign Affairs Manual (FAM) on March 25, 2021 to provide current guidance on the agency's interpretation of this ground of inadmissibility. ${ }^{30}$ Under Immigration and Nationality Act (INA) §213A, sponsors must agree to maintain (via an affidavit of support (AOS)) the intending immigrant at an income of 125 percent of the federal poverty guidelines until they become naturalized citizens or complete 40 qualifying quarters of work. The FAM reestablishes the importance of the sponsor's AOS above any other factor and returns the critical pre-2018 language: "A properly filed, non-fraudulent Form I-864, should normally be considered sufficient to satisfy the INA 212(a)(4) requirements."

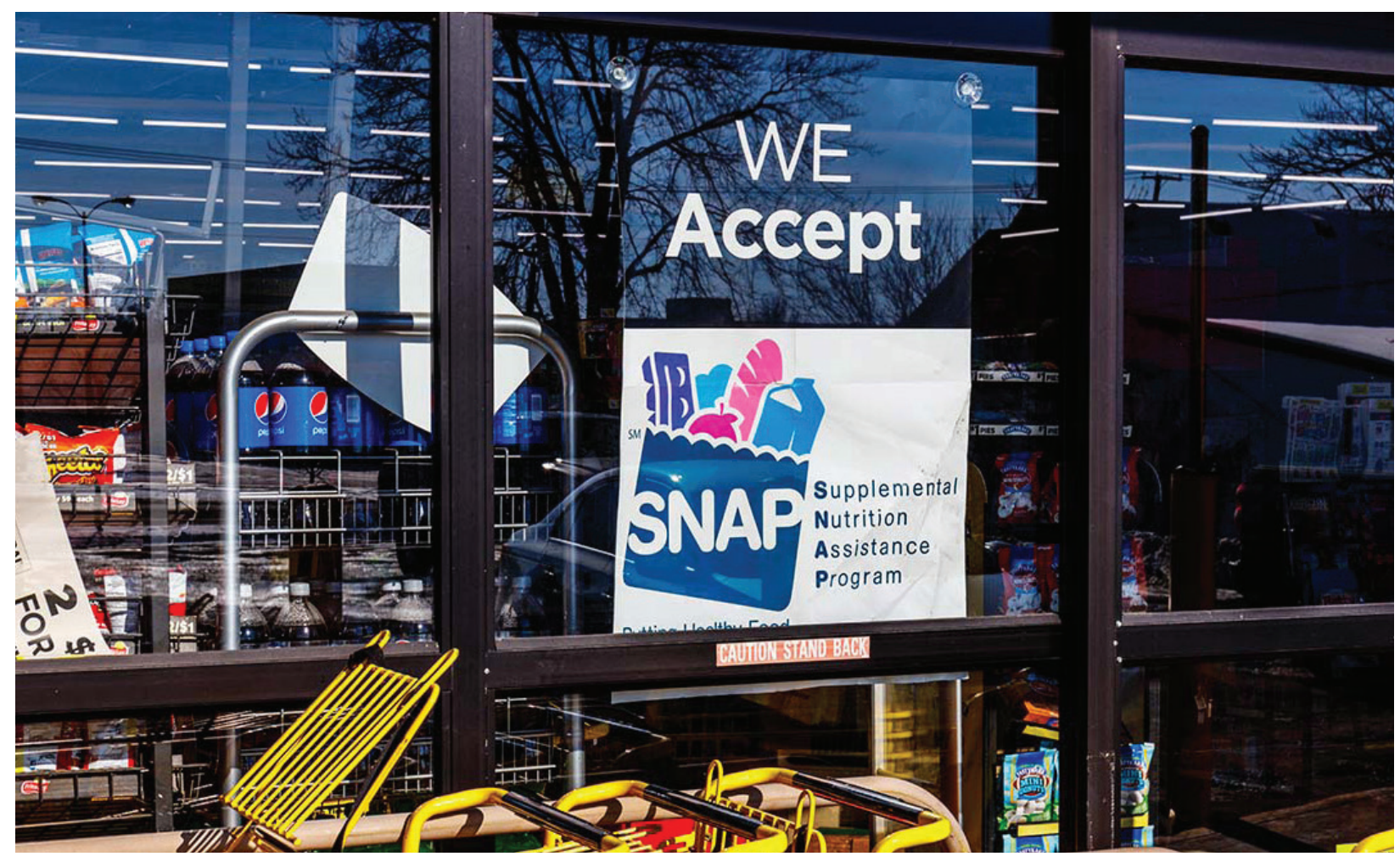

Both agencies now define public charge as "likely to become primarily dependent on the US Government for subsistence." The change in definition is significant because it (1) restores the words "primarily dependent," which means that at least half of the applicant's financial needs

28 As a result of this change, USCIS took down from its website the Form 1-944, Declaration of Self-Sufficiency, and is no longer requiring it with new adjustment of status applications, nor applying it to pending ones where the I-944 had already been filed. Applicants who received a Request for Evidence or Notice of Intent to Deny requiring the submission of an I-944 or related information with a due date on or after March 9, 2021 were informed that they do not have to submit the form or requested documentation.

29 Make the Road New York et al v. Blinken, et al, 1:19-cv-11633 (S.D.N.Y. 2020).

30 9 FAM 302.8 (Mar. 25, 2021). https://fam.state.gov/fam/09fam/09fam030208.html. 
must come from the federal government, and (2) employs the word "subsistence," which is defined very narrowly to include only three cash assistance programs. On April 12, 2021, USCIS issued an interagency letter ${ }^{31}$ which asked other federal agencies to publicize the news that the Trump-era public charge regulations were no longer in effect and that applicants and their family members should not fear receiving food stamps, Medicaid, housing, or other federal benefits, with the exception of Temporary Assistance to Needy Families and Supplemental Security Income.

\section{Muslim Bans}

On its first day in office, the Biden-Harris administration rescinded its predecessor's travel bans, which affected citizens from 13 mostly Muslim and African countries (Libya, Yemen, Iran, North Korea, Syria, Somalia, Venezuela, Myanmar, Eritrea, Kyrgyzstan, Nigeria, Sudan, and Tanzania). ${ }^{32}$ As a candidate, Biden had promised to rescind the bans, stating that "anti-Muslim bias hurts our economy, betrays our values, and can serve as a powerful terrorist recruiting tool." (Biden-Harris campaign 2020).

The bans ranged in scope, depending on the country. They prevented the granting of visas to immigrant applicants, nonimmigrant applicants, government officials and their family members, or Diversity Visa lottery winners. They affected US citizens and LPRs living in the United States who were barred from reuniting with close family members in the designated countries.

US consulates can now begin granting immigrant visa applications filed by citizens from these countries, without the need for the applicant to file a waiver. Those who had filed for waivers while the bans were in effect are now in line to have their visa applications adjudicated. Those who had filed while the bans were in effect and had been denied will soon be eligible for reconsideration of their applications.

\section{Other Travel Bans}

On February 24, 2021, the Biden-Harris administration terminated the prior administration's ban, which was twice extended, on the issuance of any immigrant visa except those for spouses and minor children of US citizens and certain immigrant investors. ${ }^{33}$ The administration also allowed a similar ban that prohibited the issuance of new visas for temporary workers and exchange visitors to expire at the end of March. The stated purpose of the bans was to prevent

31 Letter from Tracy L. Renaud, Senior Official Performing the Duties of Director, US Citizenship and Immigration Services, to Interagency Partners (April 12, 2021). https://www.uscis.gov/sites/default/files/document/notices/ SOPDD-Letter-to-USCIS-Interagency-Partners-on-Public-Charge.pdf

32 "Proclamation on Ending Discriminatory Bans on Entry to the United States" Proclamation No. 10141, 86 Fed. Reg. 7005 (January 20, 2021). (Revoking Executive Order 13780 and Proclamations 9645, 9723 and 9983). https://www. whitehouse.gov/briefing-room/presidential-actions/2021/01/20/proclamation-ending-discriminatory-bans-on-entryto-the-united-states/

33 "Revoking Proclamation 10014." Proclamation No. 1014986 Fed. Reg. 11847 (February 24, 2021). https://www. federalregister.gov/documents/2021/03/01/2021-04279/revoking-proclamation-10014. 
foreign workers from displacing and unfairly competing with US domestic workers during the pandemic recovery, despite any proof this would occur. Indeed, commentators have recognized the importance of immigrants and their ability to advance in status to the economic recovery (Svailenka 2020). Lifting the bans occurred at the same time consular offices were reopening and scheduling immigrant visa interviews for those caught in a year-long backlog.

\section{Temporary Protected Status and Other Humanitarian Relief}

The DHS Secretary may designate nationals of a "foreign state or part of a foreign state" for Temporary Protected Status based on an armed conflict, natural disaster, or other "extraordinary and temporary conditions" that prevent its nationals from safely returning. ${ }^{34}$

The Biden-Harris administration has taken several significant actions regarding TPS and DED. It has:

- Extended the TPS designation of Syria for 18 months beginning on March 31, 2021, and redesignated Syria for TPS, moving ahead the continuous presence entry date to March 19, 2021, which makes an estimated 1,800 additional Syrians (who entered after the original cut-off date) eligible for TPS; $; 5$

- Newly designated Myanmar for TPS for 18 months beginning on March 12, 2021;

- Newly designated Venezuela for TPS for 18 months beginning on March 8, 2021;36

- Formally implemented DED for Venezuelans, which had been designated but not implemented by the prior administration. In most cases, TPS is more advantageous than DED; and

- Reinstated DED for Liberia on January $20,2021 .{ }^{37}$

The Biden-Harris administration also brought back the Central American Minors (CAM) program, which allows Central American children to be reunited with parents who are "lawfully residing" in the United States. Eligible children would be granted refugee status in their home country or, alternatively, be paroled into the United States. The previous administration had terminated the CAM program after 2,700 children who were at significant risk had been approved to travel, but before they were allowed to leave their countries (Rosenberg 2017). The program will start by prioritizing the entry of previously approved children.

\section{Enforcement Priorities}

The Trump administration issued an early Executive Order, which established such broad enforcement priorities that, in effect, it prioritized the removal of all undocumented residents,

34 INA $244(b)(1)$.

3586 Fed. Reg. 14946 (March19, 2021).

3686 Fed. Reg. 13574 (March9, 2021).

37 "Memorandum on Reinstating Deferred Enforced Departure for Liberians." 86 Fed.Reg. 7055 (January 20, 2021). https://www.whitehouse.gov/briefing-room/presidential-actions/2021/01/20/reinstating-deferred-enforceddeparture-for-liberians/. 
even those without criminal records who had built family and strong equitable ties to the country. ${ }^{38}$ Its enforcement priorities were part of a broader strategy of instilling fear in undocumented immigrants and mixed-status families (Foer 2018).

On Inauguration Day, the Biden-Harris administration withdrew the prior administration's enforcement priorities and issued new, temporary ones, which it later modified and finalized on February 18, 2021. These priorities largely represented a return to Obama-era priorities. In particular, they limited Immigration and Customs Enforcement (ICE) officers to targeting: (1) national security risks; (2) recent entrants to the United States (on or after November 1, 2020) and who either entered without inspection or who later violated the terms of admission; and (3) public safety threats with certain criminal convictions or gang involvement.

This opening up of prosecutorial discretion and limiting of enforcement priorities have not only resulted in fewer undocumented persons being arrested in workplace or housing raids, but also encourages more immigrants to file petitions and applications for immigration benefits, putting them on a path to permanent residence. The USCIS's prior policy required the issuance of a Notice to Appear, which initiated removal proceedings, whenever it denied such petitions/ applications from an applicant who was not legally present. This policy had a chilling effect on:

- US citizens and LPRs who were otherwise able to petition for their close family members.

- Family members who were eligible to apply for adjustment of status.

- Victims of domestic violence.

- Persons in need of advance parole, which allows persons to leave the country knowing they will be permitted to return.

- Others in need of humanitarian relief.

This single action loosens the link between USCIS and ICE so that potential applicants are not discouraged from applying for legal immigration status.

The new enforcement priorities have also afforded a measure of security to the other members of mixed-status families, including US citizen children who do not enjoy the full rights and benefits of citizenship, given the constant threat and reality of divided and impoverished families (Ryo and Peacock 2019).

\section{"Limiting enforcement priorities has not only resulted in fewer undocumented persons being arrested in workplace or housing raids, but also encourages more immigrants to file petitions and applications for immigration benefits, putting them on a path to permanent residence."}

DHS Secretary Mayorkas has also directed ICE and CBP to place limits on immigration enforcement actions in or near courthouses. This policy supersedes an ICE directive issued

38 "Enhancing Public Safety in the Interior of the United States." Exec. Order No. 13768, 82 Fed. Reg. 8799 (January $25,2017)$. 
under the previous administration that expanded courthouse enforcement actions. The new policy states that enforcement actions can only be taken in or near a courthouse in limited circumstances. These circumstances include national security matters; imminent risk of death, violence, or physical harm; hot pursuit of a person who poses a public safety threat; and imminent risk of destruction of evidence material to a criminal case.

President Biden announced on April 27 that he had chosen Harris County, Texas, Sheriff Ed Gonzalez to head ICE. Gonzalez combines many important skills for this position: broad knowledge of law enforcement, experience managing a large police agency, and an understanding of effective enforcement priorities. He withdrew the Houston police department from the Secure Communities program, a voluntary federal program that for years helped detain and deport immigrants. He publicly criticized the program, stating, "'I do not support \#ICERaids that threaten to deport millions of undocumented immigrants, the vast majority of whom do not represent a threat to the U.S. ... The focus should always be on clear \& immediate safety threats. Not others who are not threats.'" (Sacchetti and Hernández 2021).

\section{Naturalization}

Applicants for naturalization must demonstrate "an understanding of the English language, including an ability to read, write, and speak words in ordinary usage" and "knowledge and understanding of the fundamentals of the history, and of the principles and form of government, of the United States." ${ }^{39}$ However, there are exceptions to both these requirements for persons who are unable to comply due to "physical or developmental disability or mental impairment," 40 and to the English language requirement for persons at least age 50 who have been permanent residents for 20 or more years, or age 55 who have been permanent residents for at least 15 years. ${ }^{41}$ In addition, applicants age 65 or older who have been permanent residents for at least 20 years receive "special consideration" in meeting the history and civics requirement. ${ }^{42}$

The Biden-Harris administration voided a Trump-era citizenship civics test that would have made the test longer and more difficult, especially for those with limited English language skills. It also has proposed revising the disability waiver form to simplify the process and reduce the number of questions.

\footnotetext{
39 INA §312(a).

40 INA $\S 312(b)(1)$.

41 INA $\S 312(b)(2)$.

42 INA $\S 312(b)(3)$.
} 


\section{Steps the Biden-Harris Administration Should Take to Expand Access to Permanent Residence}

USCIS has sought public comments on how it "can reduce administrative and other barriers and burdens within its regulations and policies, including those that prevent foreign citizens from easily obtaining access to immigration services and benefits." 43 This laudable initiative will likely identify many ideas for expanding access to permanent residence. A discussion of select proposals follows.

\section{Public Charge}

One of the more important steps the Biden-Harris administration could take to reduce administrative and other barriers to immigration services, benefits, and status would be to update and strengthen the agency's 1999 interim guidance on public charge.

The current guidance needs to specify exactly which federal benefits will be considered when applying the "totality of the circumstances" test, how far back adjudicators will look if the applicant received one of the benefit programs, and how far into the future the adjudicator will look to gauge whether the applicant is likely to become a public charge. DOS has already amended the Foreign Affairs Manual to clarify that submission of a legally sufficient affidavit of support should satisfy the public charge test in most cases and that the sponsor's intent-and more importantly that of the joint sponsor-is irrelevant, given that the affidavit is a legallybinding contract.

\section{"One of the more important steps the Biden-Harris administration could take to reduce barriers to immigration services, benefits, and status would be to update and strengthen the agency's 1999 interim guidance on public charge."}

The USCIS should make similar adjustments so that both agencies are applying the same standard. Finalizing such guidance into a regulation, after receiving public comments, would make the interpretation less vulnerable to alteration by a subsequent administration. It might also reduce the "chilling" effect that caused many immigrant families during the prior four years to forego needed health and nutrition programs for which they were eligible.

\section{Deferred Action for Childhood Arrivals}

President Biden has issued a memorandum directing the Secretary of DHS to "preserve and fortify" DACA. ${ }^{44}$ While the Supreme Court held that the prior administration's attempted termination of this program was unlawful, and a federal district court ordered DHS to restore the

43 US Citizenship and Immigration Services. "DHS Seeks Public Input to Identify Barriers that Limit or Prevent Access to Immigration Benefits and Services." Released April 19, 2021. https://www.uscis.gov/news/news-releases/dhsseeks-public-input-to-identify-barriers-that-limit-or-prevent-access-to-immigration-benefits-and

44 "Preserving and Fortifying Deferred Action for Childhood Arrivals (DACA)." 86 Fed. Reg. 7053 (January 25, 2021). https://www.whitehouse.gov/briefing-room/presidential-actions/2021/01/20/preserving-and-fortifying-deferredaction-for-childhood-arrivals-daca/?ct=t(AgencyUpdate 012120) 
original program, DACA remains vulnerable to termination. A federal judge in Texas is poised to rule on its legality.

DHS should issue regulations that expand the DACA program by updating the eligibility guidelines to allow more people to qualify. In particular, DHS should:

- Make DACA available to those who were under 18 (as opposed to 16) when they first entered the United States.

- Move up the continuous residence date from June 15, 2007 to June 15, 2016 and move up the physical presence date from June 15, 2012 to January 1, 2021.

- Allow applicants prevented from applying for DACA because the former president cancelled the program to do so under the reinstated program.

- Relax the eligibility requirements for advance parole, which was limited under the original policy to travel for humanitarian, educational, or employment purposes: this would allow DACA recipients to travel abroad for any purpose, including simply to visit family.

- Confirm that DACA recipients who travel and return to the United States with advance parole are considered "inspected and admitted or paroled" for adjustment of status purposes under INA § 245(a).

Expanding advance parole accessibility and issuing clear guidance regarding the legal effect of such travel would mean that more DACA recipients who are immediate relatives of US citizens and who meet the other requirements could become eligible for adjustment of status after returning to the United States in parole status.

\section{Other Humanitarian Relief}

Non-governmental organizations (NGOs) have advocated for redesignations or new designations of TPS to countries devastated by Hurricane Eta and Hurricane lota, which struck Central America at the end of 2020. These countries include Honduras, Nicaragua, Guatemala, Haiti, and the Bahamas. The administration should also grant an 18-month extension and redesignation of TPS for Yemen, Somalia, and South Sudan. It should also consider designating TPS to certain African countries, including Mauritania, Cameroon, Guinea, and Sierra Leone.

The Biden-Harris administration should also extend the December 2021 deadline for filing for permanent residence under the Liberian Refugee and Immigration Fairness (LRIF) program. LRIF originally applied to Liberian nationals who applied by December 20, 2020, although this deadline was extended to December 20, 2021. ${ }^{45} \mathrm{NGO}$ advocates have also requested that the

45 To qualify for permanent residence under LRIF, applicants must: (1) have lived continuously in the United States since November 20, 2014; (2) be admissible or eligible for a waiver of inadmissibility; (3) not have been convicted of an aggravated felony or two or more crimes of moral turpitude; and (4) not have persecuted others on account of race, religion, nationality, membership in a particular social group, or political opinion. The spouses, unmarried children under age 21, and unmarried children 21 years or older of a qualifying Liberian are also eligible for relief. 
administration make changes to LRIF, which would expand eligibility for this program. ${ }^{46}$

\section{TPS and Adjustment of Status}

As discussed, the INA provides that an applicant for adjustment of status must have been "inspected and admitted or parole." ${ }^{47}$ Many TPS beneficiaries have resided in the United States for extended periods (Warren and Kerwin 2017) and are eligible for immigrant visas or adjustment of status as "immediate relatives" of US citizens. ${ }^{48}$

Statutory language, as interpreted by a number of courts, indicates that a grant of TPS constitutes a "lawful admission" for purposes of eligibility for adjustment. In a typical fact pattern, a person enters the United States without inspection, applies for and is granted TPS, and thereafter becomes the beneficiary of an approved I-130 petition (as an immediate relative) filed by a US citizen spouse or child over 21 years of age.

INA §244(f)(4) specifies that a TPS holder "for purposes of adjustment of status under section 1255 . . . shall be considered as being in, and maintaining lawful status as a nonimmigrant." Nonimmigrants, by definition, have been inspected and admitted to the United States. The plain reading of the provision is that a grant of TPS creates an admission that can qualify the recipient for adjustment of status if the other requirements are satisfied. Yet US circuit courts are split on this issue. The Sixth, Eighth, and Ninth Circuits have held that a grant of TPS is an admission for adjustment purposes. The Third and Eleventh Circuit Courts have held that it is not. As a result, USCIS is bound only to recognize a TPS grant as an admission for INA § 245(a) adjustment applicants residing in three federal circuits.

After years of inconsistent treatment, the US Supreme Court accepted certiorari in the Third Circuit case. ${ }^{49}$ It held oral argument on April 19, 2021 and the conservative majority seemed to forecast its intention to interpret the provision in the more restrictive manner. The Court is poised to issue a decision resolving this question by June 2021. The Biden-Harris administration may have missed an opportunity to adopt the more liberal interpretation of INA $\S 244(f)(4)$, which would have benefited thousands of TPS recipients from El Salvador, Haiti, Honduras, Nicaragua, Nepal, and other countries. Once the Court issues its decision, these recipients will have to consular process abroad, rather than adjust status in the United States. Consular

46 In particular, they have proposed:

- Bringing the relevant USCIS Policy Manual provisions in line with the statutory language.

- Expanding the list of acceptable documentation of nationality.

- Using the date of arrival rather than the date of residence for purposes of the adjustment rollback date.

- Implementing a waiver of in-person interviews for applications that are prima facie approvable.

- Conducting meaningful outreach and engagement with the Liberian community.

47 INA $§ 245(a)$.

48 Immediate relatives include the spouses, parents, and children of US citizens.

49 Sanchez v. Sec'y of Dept. of Homeland Security, 967 F.3d 242 (3rd Cir. 2020). 
processing requires intending immigrants to secure a waiver of the unlawful presence ground of inadmissibility and to take other risks. ${ }^{50}$

The Biden-Harris administration can still, however, take two remedial actions. First, it should overturn an Administrative Appeals Office decision, ${ }^{51}$ which held that TPS recipients return from abroad with the "same immigration status" they had in departing and are not considered to be "inspected and admitted or paroled." DHS should issue a clarifying memorandum indicating that TPS beneficiaries who leave the country on advance parole and return are, in fact, considered "inspected and admitted or paroled" for purposes of adjustment of status. At present, only those who departed on advance parole prior to August 20, 2020 and who are immediate relatives can qualify for adjustment. The Trump administration applied a tortured reading of the Miscellaneous and Technical Immigration and Naturalization Amendments of 1991 (MITNA) to arrive at this current interpretation of the law, which overturned almost 30 years of precedent. It would be a simple act to reverse this AAO decision and return to pre-Trump policy and practice.

The second change would be to undo the agency's interpretation ${ }^{52}$ that a departure and return on advance parole does not execute an outstanding removal order. At present, these TPS recipients are considered to be still in proceedings and under the jurisdiction of the Executive Office for Immigration Review. If such a return on advance parole were to execute the removal order, which was the prior interpretation, those who returned would not have to negotiate with district counsel and move to reopen their removal proceedings before an immigration judge-a complex and often unsuccessful endeavor. This change would allow those TPS recipients who are immediate relatives of US citizens to file for adjustment with USCIS, together with a Form I-212 to waive the removal order ground of inadmissibility. The Biden administration can easily remedy this problem by replacing the policy memorandum and settling a lawsuit ${ }^{53}$ that challenges the current interpretation.

\section{Extreme Vetting and Backlogs}

When campaigning for presidency, Donald Trump announced that if elected he would impose "extreme vetting" measures on visa applicants and refugees. ${ }^{54}$ As expected, these measures have resulted in lengthy delays for immigrant and nonimmigrant visa applicants, as well as their counterparts applying for adjustment of status. This same "get-tough" approach resulted in near historic processing delays of common family-based applications and petitions.

50 The Solicitor General could have withdrawn the certiorari petition, even after the Supreme Court had granted it, and then the split in the circuits would have remained. At that point, the Attorney General could have written an opinion adopting the liberal interpretation. However, this did not occur.

51 Matter of Z-R-Z-C-, Adopted Decision 2020-02 (AAO Aug. 20, 2020).

52 USCIS Policy Alert, Effect of Travel Abroad by Temporary Protected Status Beneficiaries with Final Orders of Removal, PA-2019-12 (Dec. 20, 2019).

53 Central American Resource Center v. Cuccinelli II, Case No. 20-cv-02363 (RBW) (D. D.C. 2020).

54 Refugees, in particular, already undergo extensive and lengthy vetting and background checks before being approved for admission (Kerwin and Nicholson 2021). 
For example, an LPR filing an initial I-130 petition to immigrate his spouse or unmarried child can expect to wait up to two years for the California Service Center to adjudicate the petition. Yet the second preference category is now current, meaning that visas are available as soon as the petition is approved. For a US citizen filing to immigrate a married son or daughter, the processing time at the California Service Center is over 10 years. For a conditional LPR applying to remove the conditions, the processing time at the California Service Center is approximately two years, while for applications filed at the Nebraska Service Center, the wait is even longer. The processing time for adjustment of status applications adjudicated at the local district level averages about two years, although in some districts (e.g., Baltimore, Brooklyn) the delay is almost double that. USCIS also eliminated the 90-day processing requirement for Employment Authorization Documents (EADs), meaning that it now takes months to receive the initial work authorization.

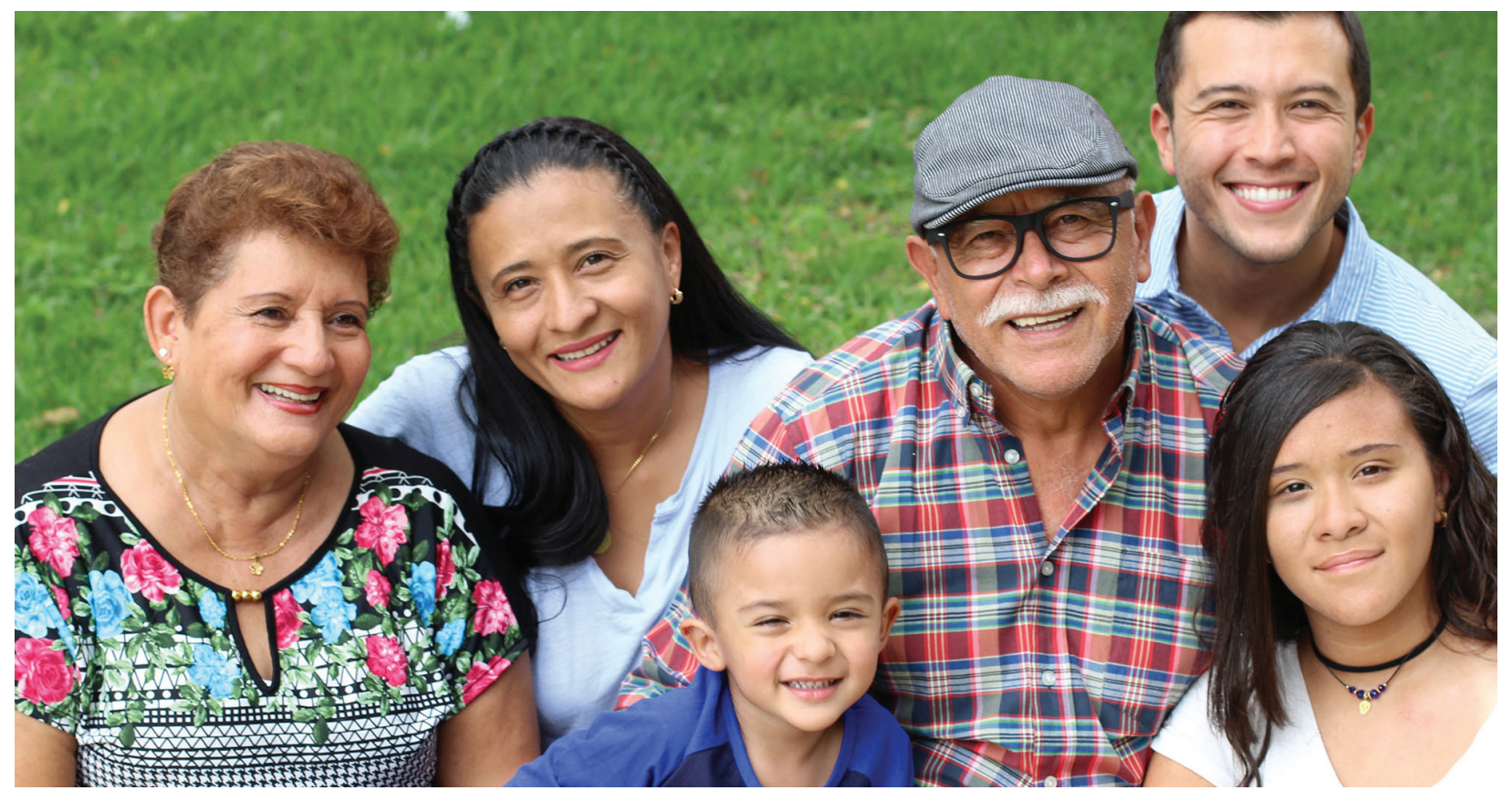

While "extreme vetting" has added time and burden to the process, other policy changes have also contributed to the backlog. One is the unnecessary expansion of in-person interview requirements. Cases with small errors or issues that were previously resolved through customer service and InfoPass appointments are being denied, forcing applicants to start from the beginning and thus resulting in USCIS repeating adjudicatory steps. Changes in the USCIS'S Request for Evidence (RFE) policy now allow the agency to deny applications and petitions rather than issuing an RFE or a Notice of Intent to Deny (NOID) to obtain additional information or documentary proof. In addition to creating further delay, this places an unfair financial burden on applicants, forcing them to pay filing fees to refile a case.

President Biden has ordered a review of some of Trump's "enhanced security measures," as well as those that preceded the prior administration. He has also taken one small step resulting from this review and issued guidance that reverses a Trump policy with regard to the deference officers should give to previous decisions (USCIS 2021b, Vol. 2). This new guidance restores the 
prior policy and instructs officers to defer to prior determinations of eligibility when adjudicating extension requests involving the same parties and facts as the initial petition or application unless there was a material error, material change, or new material facts.

When cases drag on for months and years, applicants can lose the ability to travel, work, drive, and plan for the future, with all the negative consequences for them and their families. The administration should reduce application processing delays by prioritizing the adjudication of family-based petitions and applications, end the "extreme vetting" and unnecessary investigations, restore the InfoPass system to resolve cases with small errors or challenges, and reinstate the policy requiring adjudicators to issue an RFE or NOID before issuing a denial.

\section{"When cases drag on for months and years, applicants can lose the ability to travel, work, drive, and plan for the future, with all the negative consequences for them and their families."}

\section{Access to USCIS District Offices}

The program allowing applicants to self-schedule in-person appointments at USCIS field offices, called InfoPass, had worked successfully for the agency and applicants alike for two decades. USCIS ended InfoPass in 2019. The agency's stated intention in ending the program was to make appointments "more accessible" by routing all requests through the USCIS Contact Center and, in Orwellian style, naming the program Information Services Modernization. Instead of being able to schedule a walk-in appointment online with the USCIS to request, for example, emergency advance parole or proof of LPR status, people now must call the USCIS Contact Center and explain the basis for their request for an in-person appointment. A Tier 2 officer will determine if an in-person appointment is appropriate and, if so, will schedule the appointment. USCIS has also terminated the use of Service Center email addresses for case inquires in order to streamline requests for case assistance and to focus its resources on its online, self-help tools.

The USCIS's "modernization" efforts make it far more difficult to resolve specific case problems, obtain collateral relief, or determine the status of an application. They also disproportionately affect vulnerable and disabled immigrants, individuals with low English proficiency or literacy, pro se applicants, and people facing urgent humanitarian situations. Contact Center personnel lack sufficient training to discern when an InfoPass appointment is necessary and lack sufficient access to information from files that are located at Field Offices. The Biden-Harris administration should restore the InfoPass walk-in system and make USCIS personnel more-not lessaccessible to the public and practitioners trying to resolve individual case problems.

"The Biden-Harris administration should restore the InfoPass walk-in system and make USCIS personnel more-not less-accessible to the public and practitioners trying to resolve individual case problems." 


\section{Naturalization Determinants and Naturalization Rates by State, Metropolitan Area, and Country of Birth}

This section begins with a brief discussion of the CMS' methodology for estimating naturalization rates. It then examines the effects of three variables on naturalization rates: financial resources, English proficiency, and level of education. This analysis suggests that a successful naturalization initiative would need to address key factors and underlying conditions that go beyond naturalization processes and requirements.

The section then pivots to show eligible-to-naturalization populations and naturalization rates for selected states, metropolitan areas, and countries of birth in 2019. It identifies areas where naturalization rates should be increased by policy and programmatic interventions. It also shows where naturalizations are relatively high but large numbers of immigrants have not yet naturalized.

Finally, the section shows that naturalization rates have undergone a shift from 2010 to 2019, with immigrants from China and India naturalizing at relatively lower rates and the naturalization of immigrants from Central America and Mexico increasing considerably. The fact these latter rates are rising make it an excellent time to implement programs to further increase naturalization rates from these countries.

\section{"From 2010 to 2019, naturalization of immigrants from Central America and Mexico increased considerably. The fact that these rates are rising make it an excellent time to implement programs to further increase naturalization rates from these countries."}

\section{Methodology and Terms}

CMS derived these estimates from 2010 and 2019 data collected in the US Census Bureau's American Community Survey (ACS). Because undocumented residents cannot naturalize, they have been removed from the data used to compile naturalization rates. Their inclusion would understate naturalization rates and would skew rates among countries with differing undocumented population sizes. CMS's estimation procedures are described in the next section.

The tables show data for the naturalized population and the eligible-to-naturalize population. ${ }^{55}$ In the text and the tables, the phrase "legal population" or "the population" refers to the sum of the naturalized population plus the population eligible to naturalize. Data for the naturalized population were compiled directly from the ACS. Estimates of the eligible-to-naturalize population include the following groups: ${ }^{56}$

1. Noncitizens that arrived before 2014 compiled from 2019 ACS data.

\footnotetext{
55 Noncitizens must be 18 years of age or older to become naturalized citizens. The data described here includes noncitizens younger than age 18 because minors become US citizens upon the naturalization of their parents.

56 All steps were carried out at the microdata level so that the rich diversity of the ACS data would be preserved. The results were adjusted slightly to account for undercount in the ACS.
} 
2. Minus, CMS estimates of undocumented residents counted in the ACS. ${ }^{57}$

3. Plus, a small number of noncitizens that arrived after 2014 and could be eligible to naturalize after fewer than five years in the US - certain refugees, those married to US citizens, and active-duty military.

A small adjustment was made to account for underreporting in the ACS.

In this report, the "eligible-to-naturalize" population refers almost exclusively to LPRs, or green card holders. The legal foreign-born population is the sum of the naturalized population and the population that is eligible to naturalize. A note on terminology: The tables show the Census Bureau's designations of metropolitan areas, but the names are shortened in the text. For example, ChicagoNaperville-Elgin, IL-IN-WI in the tables becomes "the Chicago area" in the text of the report.

\section{Major Determinants of Naturalization}

CMS examined three variables that are likely to affect naturalization rates: financial resources, English proficiency, and level of education. The estimates described here are for immigrants that arrived in the 1991 to 2001 period. These immigrants have had 18 years on average to naturalize. Keeping the duration of residence constant assures comparability of the statistics for the naturalized and eligible-to-naturalize populations.

Table 1 compares naturalization rates for (1) those who speak only or mostly English versus those who speak little or no English, and (2) those with more than a high school education versus those with less than a high school education. The fact that naturalization rates are higher for immigrants that are fluent in English and that have more education is not surprising. The differences shown in Table 1, column 3, are in the expected direction. The fact that the rates are a remarkable three or four times higher for the groups that are fluent in English and have attended college illustrates the strength of these variables in determining naturalization rates. ${ }^{58}$

\section{"Three variables are likely to affect naturalization rates: financial resources, English proficiency, and level of education."}

Nationally, almost half (48 percent) of those fluent in English and those with higher levels of education had naturalized by 2019 (Table 1). Only 11 percent of those less fluent in English or with relatively low levels of education had naturalized. The rates of naturalization by state do not vary much from the average US rate. This is as expected because, with some exceptions, immigrants from more than 200 countries of origin are dispersed across the country.

Naturalization rates, however, vary by country of origin, even across populations with the same English skills and educational levels. About 75 percent of immigrants from India who are fluent in English have naturalized, for example, compared to just 25 percent for Mexico, 27 percent

57 The CMS methodology for estimating undocumented residents is described in the Appendix of Warren (2021).

58 An earlier CMS study found that income and naturalization rates rose as age, length of residence, English language proficiency, and educational attainment increased (Warren and Kerwin 2015, 317). 
for El Salvador, and 33 percent for Guatemala (Table 1). This same pattern is observed for welleducated immigrants. The variation in these naturalization rates by country of origin can probably be explained by the differences in median income of the eligible-to-naturalize population from these countries (Table 2, column 2). The median household income for India $(\$ 142,000)$ is more than twice the average for Mexico, El Salvador, and Guatemala $(\$ 58,200)$. This finding indicates that while English proficiency and college attendance greatly increase naturalization rates, they are insufficient if financial resources are not available.

Table 1. Naturalization Rates by Select Countries of Origin and US States of the Legal Foreignborn Population, as of 2019: Average of 23 Years in the United States*

Top 5 countries and top 5 states for naturalized population.

\begin{tabular}{|c|c|c|c|}
\hline Country and state & Speak only or mostly English & Speak little or no English & Difference \\
\hline & (1) & (2) & $(3)=(1)-(2)$ \\
\hline US total & $48 \%$ & $11 \%$ & $37 \%$ \\
\hline Mexico & $25 \%$ & $11 \%$ & $14 \%$ \\
\hline India & $75 \%$ & $5 \%$ & $70 \%$ \\
\hline China & $40 \%$ & $21 \%$ & $19 \%$ \\
\hline El Salvador & $27 \%$ & $13 \%$ & $14 \%$ \\
\hline Guatemala & $33 \%$ & $14 \%$ & $19 \%$ \\
\hline California & $41 \%$ & $13 \%$ & $28 \%$ \\
\hline Texas & $44 \%$ & $10 \%$ & $34 \%$ \\
\hline New York & $49 \%$ & $14 \%$ & $35 \%$ \\
\hline Florida & $49 \%$ & $14 \%$ & $35 \%$ \\
\hline Illinois & $47 \%$ & $10 \%$ & $37 \%$ \\
\hline Country and state & More than high school education & Less than high school education & Difference \\
\hline US total & $48 \%$ & $11 \%$ & $38 \%$ \\
\hline Mexico & $18 \%$ & $16 \%$ & $2 \%$ \\
\hline India & $79 \%$ & $5 \%$ & $75 \%$ \\
\hline China & $56 \%$ & $13 \%$ & $43 \%$ \\
\hline El Salvador & $21 \%$ & $19 \%$ & $2 \%$ \\
\hline Guatemala & $27 \%$ & $18 \%$ & $9 \%$ \\
\hline California & $46 \%$ & $11 \%$ & $34 \%$ \\
\hline Texas & $43 \%$ & $11 \%$ & $32 \%$ \\
\hline New York & $48 \%$ & $12 \%$ & $36 \%$ \\
\hline Florida & $48 \%$ & $11 \%$ & $37 \%$ \\
\hline Illinois & $49 \%$ & $10 \%$ & $39 \%$ \\
\hline
\end{tabular}

*Population that arrived 1991 to 2001

Source: Center for Migration Studies. See text for methods of estimation. 
Table 2. Selected Characteristics of the Legal Foreign-born Population, by Country, in 2019: Average of 23 Years in the United States

Top 5 countries for eligible to naturalize population.

\begin{tabular}{|c|c|c|c|}
\hline \multirow[b]{2}{*}{ Country of origin } & \multirow[b]{2}{*}{ Naturalized } & \multicolumn{2}{|c|}{ Population that arrived 1991 to 2001} \\
\hline & & Eligible to naturalize & Difference \\
\hline & (1) & (2) & $(3)=(1)-(2)$ \\
\hline \multirow[t]{2}{*}{ Population } & $6,631,500$ & $2,262,900$ & - \\
\hline & \multicolumn{3}{|c|}{ Median household income - Top 5 countries } \\
\hline US total & $\$ 94,800$ & $\$ 69,000$ & $\$ 25,800$ \\
\hline Mexico & $\$ 72,200$ & $\$ 58,500$ & $\$ 13,700$ \\
\hline India & $\$ 184,300$ & $\$ 142,900$ & $\$ 41,400$ \\
\hline China & $\$ 115,010$ & $\$ 74,800$ & $\$ 40,210$ \\
\hline El Salvador & $\$ 86,000$ & $\$ 61,100$ & $\$ 24,900$ \\
\hline \multirow[t]{2}{*}{ Guatemala } & $\$ 84,100$ & $\$ 55,000$ & $\$ 29,100$ \\
\hline & \multicolumn{3}{|c|}{ Percent of households with median incomes $>125 \%$ of poverty level } \\
\hline US total & $87 \%$ & $80 \%$ & $7 \%$ \\
\hline Mexico & $83 \%$ & $74 \%$ & $9 \%$ \\
\hline India & $95 \%$ & $94 \%$ & $1 \%$ \\
\hline China & $84 \%$ & $78 \%$ & $6 \%$ \\
\hline El Salvador & $88 \%$ & $80 \%$ & $8 \%$ \\
\hline \multirow[t]{2}{*}{ Guatemala } & $86 \%$ & $71 \%$ & $15 \%$ \\
\hline & \multicolumn{3}{|c|}{ Median household income - Top 5 states } \\
\hline US total & $\$ 94,800$ & $\$ 69,000$ & $\$ 25,800$ \\
\hline California & $\$ 109,000$ & $\$ 68,000$ & $\$ 41,000$ \\
\hline Texas & $\$ 87,200$ & $\$ 64,200$ & $\$ 23,000$ \\
\hline New York & $\$ 91,000$ & $\$ 68,400$ & $\$ 22,600$ \\
\hline Florida & $\$ 74,000$ & $\$ 64,000$ & $\$ 10,000$ \\
\hline \multirow[t]{2}{*}{ Illinois } & $\$ 97,300$ & $\$ 70,000$ & $\$ 27,300$ \\
\hline & \multicolumn{3}{|c|}{ Percent of households with median incomes $>125 \%$ of poverty level } \\
\hline US total & $87 \%$ & $80 \%$ & $7 \%$ \\
\hline California & $87 \%$ & $75 \%$ & $12 \%$ \\
\hline Texas & $86 \%$ & $77 \%$ & $9 \%$ \\
\hline New York & $84 \%$ & $79 \%$ & $6 \%$ \\
\hline Florida & $85 \%$ & $80 \%$ & $5 \%$ \\
\hline Illinois & $87 \%$ & $82 \%$ & $5 \%$ \\
\hline
\end{tabular}

Source: Center for Migration Studies. See text for methods of estimation. 
The data on median household income in Table 2 demonstrates the financial gain from naturalization, which has been characterized as the citizenship "wage premium" (NAS 2015, 165; Warren and Kerwin 2015, 315). Percent gain in median household income - for persons in the country for the same length of time - ranges from about 20 percent for Mexico to 35 percent for China and Guatemala (Table 2).

The data in the second panel in Table 2 shows the percent of households with median incomes higher than 125 percent of the poverty level. The percentages are slightly higher for naturalized, but the differences are less than 10 percent (except Guatemala). The relatively high percentages of median incomes greater than 125 percent of the poverty level for the eligible-to-naturalize population might indicate that a large portion of the population has sufficient financial resources to naturalize. Nationwide, 80 percent of eligible-to-naturalize live in households with income higher than 125 percent of the poverty level.

The data shown in Tables 1 and 2 indicate that English proficiency and higher levels of education are important drivers and determinants of naturalization, but naturalization rates are also dependent on sufficient income levels. For example, 75 percent of immigrants from India that speak only or mostly English are naturalized, but only 25 percent of immigrants from Mexico with the same language skills are naturalized (Table 1). This disparity could be explained by the relatively higher median household income of Indians that are eligible to naturalize $-\$ 142,900$ for India and \$58,500 for Mexico (Table 2).

On the other hand, the percentage of households with median incomes more than 125 percent of the poverty level (80 percent nationally) indicates that low income alone is not the primary factor inhibiting naturalization. The data shown here indicate that all three factors assessed in this paper - English proficiency, education, and financial resources - are important determinants of naturalization rates.

\section{"The percentage of households with median incomes more than 125 percent of the poverty level indicates that low income alone is not the primary factor inhibiting naturalization."}

\section{Naturalization Rates in 2019}

Table 3 shows naturalization rates for the 25 states with the largest eligible-to-naturalization populations. Indiana, Arizona, and Texas had the lowest rates, 67 percent for all three, well below the national average of 74 percent. The next seven states - Wisconsin, Washington, California, North Carolina, Oregon, Tennessee, and Colorado - were slightly below the national average, and 15 of the 25 states shown in Table 3 were at or above the US average.

Attention on the states that have relatively low naturalization rates should not minimize the opportunities for additional naturalization in other states. For example, California has about 2.1 million who are eligible to naturalize, and the eight states with the highest naturalization rates in Table 3 have a total of 1.8 million eligible-to-naturalize. 
Table 3. Naturalization Rates for the 25 States with the Largest Eligible-to-Naturalize Population in 2019.

Numbers in thousands.

Ranked by percent naturalized (column 4)

\begin{tabular}{|c|c|c|c|c|}
\hline State of residence & Naturalized & Eligible to naturalize & Legal foreign-born & Percent naturalized \\
\hline & (1) & (2) & $(3)=(1)+(2)$ & $(4)=(1) /(3)$ \\
\hline US Total & 23,095 & 8,102 & 31,197 & $74 \%$ \\
\hline Indiana & 149 & 75 & 223 & $67 \%$ \\
\hline Arizona & 437 & 217 & 654 & $67 \%$ \\
\hline Texas & 1,954 & 943 & 2,897 & $67 \%$ \\
\hline Wisconsin & 137 & 56 & 193 & $71 \%$ \\
\hline Washington & 532 & 211 & 743 & $72 \%$ \\
\hline California & 5,654 & 2,123 & 7,777 & $73 \%$ \\
\hline North Carolina & 357 & 134 & 492 & $73 \%$ \\
\hline Oregon & 200 & 75 & 275 & $73 \%$ \\
\hline Tennessee & 158 & 59 & 217 & $73 \%$ \\
\hline Colorado & 262 & 97 & 359 & $73 \%$ \\
\hline Georgia & 497 & 176 & 673 & $74 \%$ \\
\hline Massachusetts & 645 & 217 & 862 & $75 \%$ \\
\hline Connecticut & 282 & 94 & 376 & $75 \%$ \\
\hline Illinois & 949 & 315 & 1,264 & $75 \%$ \\
\hline Hawaii & 163 & 52 & 214 & $76 \%$ \\
\hline Nevada & 308 & 98 & 405 & $76 \%$ \\
\hline New York & 2,584 & 811 & 3,396 & $76 \%$ \\
\hline Michigan & 370 & 109 & 478 & $77 \%$ \\
\hline Florida & 2,594 & 758 & 3,353 & $77 \%$ \\
\hline Maryland & 484 & 141 & 625 & $77 \%$ \\
\hline Ohio & 292 & 85 & 377 & $78 \%$ \\
\hline Virginia & 586 & 165 & 750 & $78 \%$ \\
\hline Pennsylvania & 493 & 135 & 628 & $79 \%$ \\
\hline New Jersey & 1,212 & 304 & 1,516 & $80 \%$ \\
\hline Minnesota & 283 & 70 & 353 & $80 \%$ \\
\hline
\end{tabular}

Source: Center for Migration Studies. See text for methods of estimation.

Table 4 shows naturalization rates in 2019 for the 25 metro areas with the largest eligible-tonaturalize population. Fresno had the lowest rate at 58 percent, followed by Phoenix (66 percent), San Antonio (67 percent), and Austin (67 percent). The New York metro area had a relatively high naturalization rate (77 percent), but it also represents the most significant opportunity for increasing total naturalizations, with about one million eligible to naturalize (Table 4). The highest rates of naturalization were in the Philadelphia area (79 percent) and the Detroit area (80 percent). 
Table 4. Naturalization Rates for the 25 Metro Areas with the Largest Eligible-to-Naturalize Population in 2019.

Numbers in thousands.

Ranked by percent naturalized (column 4)

Metropolitan area

Naturalized Eligible to naturalize Legal foreign-born Percent naturalized

\begin{tabular}{|c|c|c|c|c|}
\hline & (1) & (2) & $(3)=(1)+(2)$ & $(4)=(1) /(3)$ \\
\hline US Total & 23,095 & 8,102 & 31,197 & $74 \%$ \\
\hline Fresno, CA & 88 & 64 & 152 & $58 \%$ \\
\hline Phoenix-Mesa-Scottsdale, AZ & 306 & 158 & 464 & $66 \%$ \\
\hline San Antonio-New Braunfels, TX & 124 & 62 & 186 & $67 \%$ \\
\hline Austin-Round Rock, TX & 136 & 68 & 203 & $67 \%$ \\
\hline Dallas-Fort Worth-Arlington, TX & 541 & 246 & 787 & $69 \%$ \\
\hline Houston-The Woodlands-Sugar Land, TX & 699 & 284 & 982 & $71 \%$ \\
\hline Los Angeles-Long Beach-Anaheim, CA & 2,330 & 900 & 3,229 & $72 \%$ \\
\hline Riverside-San Bernardino-Ontario, CA & 541 & 208 & 750 & $72 \%$ \\
\hline Seattle-Tacoma-Bellevue, WA & 372 & 140 & 512 & $73 \%$ \\
\hline Denver-Aurora-Lakewood, CO & 184 & 65 & 249 & $74 \%$ \\
\hline Boston-Cambridge-Newton, MA-NH & 494 & 172 & 665 & $74 \%$ \\
\hline Atlanta-Sandy Springs-Roswell, GA & 403 & 135 & 538 & $75 \%$ \\
\hline Chicago-Naperville-Elgin, IL-IN-WI & 900 & 292 & 1,191 & $76 \%$ \\
\hline San Diego-Carlsbad, CA & 446 & 141 & 587 & $76 \%$ \\
\hline Tampa-St. Petersburg-Clearwater, FL & 254 & 80 & 334 & $76 \%$ \\
\hline Las Vegas-Henderson-Paradise, NV & 258 & 81 & 338 & $76 \%$ \\
\hline San Jose-Sunnyvale-Santa Clara, CA & 428 & 127 & 555 & $77 \%$ \\
\hline Sacramento-Roseville-Arden-Arcade, CA & 251 & 74 & 325 & $77 \%$ \\
\hline New York-Newark-Jersey City, NY-NJ-PA & 3,426 & 1,009 & 4,435 & $77 \%$ \\
\hline San Francisco-0akland-Hayward, CA & 854 & 241 & 1,095 & $78 \%$ \\
\hline Miami-Fort Lauderdale-West Palm Beach, FL & 1,515 & 427 & 1,943 & $78 \%$ \\
\hline Washington-Arlington-Alexandria, DC-VA-MD-WV & 761 & 214 & 974 & $78 \%$ \\
\hline Orlando-Kissimmee-Sanford, FL & 252 & 70 & 322 & $78 \%$ \\
\hline Philadelphia-Camden-Wilmington, PA-NJ-DE-MD & 374 & 101 & 475 & $79 \%$ \\
\hline Detroit-Warren-Dearborn, MI & 250 & 62 & 313 & $80 \%$ \\
\hline
\end{tabular}

Source: Center for Migration Studies. See text for methods of estimation. 
Table 5. Percent Naturalized in Arizona, California, and Texas, with Metro Areas that Had 18,000 or More Eligible to Naturalize in 2019

Numbers in thousands.

Ranked by percent naturalized (column 4)

\begin{tabular}{|c|c|c|c|c|}
\hline State and metropolitan area & Naturalized & Eligible to naturalize & Legal foreign-born & Percent naturalized \\
\hline & (1) & (2) & $(3)=(1)+(2)$ & $(4)=(1) /(3)$ \\
\hline US Total & 23,095 & 8,102 & 31,197 & $74 \%$ \\
\hline Arizona & 437 & 217 & 654 & $67 \%$ \\
\hline Yuma & 27 & 14 & 41 & $65 \%$ \\
\hline Phoenix-Mesa-Scottsdale & 306 & 158 & 464 & $66 \%$ \\
\hline Tucson & 64 & 29 & 92 & $69 \%$ \\
\hline Rest of Arizona & 40 & 17 & 57 & $71 \%$ \\
\hline California & 5,654 & 2,123 & 7,777 & $73 \%$ \\
\hline Salinas & 40 & 36 & 77 & $52 \%$ \\
\hline Visalia-Porterville & 39 & 31 & 70 & $56 \%$ \\
\hline Bakersfield & 64 & 49 & 113 & $57 \%$ \\
\hline Fresno & 88 & 64 & 152 & $58 \%$ \\
\hline Santa Maria-Santa Barbara & 34 & 20 & 55 & $63 \%$ \\
\hline Modesto & 55 & 32 & 87 & $64 \%$ \\
\hline Stockton-Lodi & 91 & 38 & 129 & $70 \%$ \\
\hline Los Angeles-Long Beach-Anaheim & 2,330 & 900 & 3,229 & $72 \%$ \\
\hline Riverside-San Bernardino-Ontario & 541 & 208 & 750 & $72 \%$ \\
\hline Oxnard-Thousand Oaks-Ventura & 97 & 37 & 134 & $72 \%$ \\
\hline San Diego-Carlsbad & 446 & 141 & 587 & $76 \%$ \\
\hline San Jose-Sunnyvale-Santa Clara & 428 & 127 & 555 & $77 \%$ \\
\hline Sacramento-Roseville-Arden-Arcade & 251 & 74 & 325 & $77 \%$ \\
\hline San Francisco-Oakland-Hayward & 854 & 241 & 1,095 & $78 \%$ \\
\hline Rest of California & 295 & 124 & 419 & $70 \%$ \\
\hline Texas & 1,954 & 943 & 2,897 & $67 \%$ \\
\hline McAllen-Edinburg-Mission & 68 & 61 & 129 & $53 \%$ \\
\hline Laredo & 21 & 18 & 39 & $54 \%$ \\
\hline Brownsville-Harlingen & 37 & 27 & 64 & $58 \%$ \\
\hline San Antonio-New Braunfels & 124 & 62 & 186 & $67 \%$ \\
\hline Austin-Round Rock & 136 & 68 & 203 & $67 \%$ \\
\hline El Paso & 99 & 45 & 144 & $69 \%$ \\
\hline Dallas-Fort Worth-Arlington & 541 & 246 & 787 & $69 \%$ \\
\hline Houston-The Woodlands-Sugar Land & 699 & 284 & 982 & $71 \%$ \\
\hline Rest of Texas & 230 & 133 & 363 & $63 \%$ \\
\hline
\end{tabular}

Source: Center for Migration Studies. See text for methods of estimation. 
A program to increase naturalization rates would be strengthened by more detailed data for small areas. For example, even though the Detroit area has a relatively high naturalization rate ( 80 percent), it has immigrants from countries that have a wide range of naturalization rates. The 62,000 eligible-to-naturalize in the Detroit area (Table 4) includes about 8,000 from Canada and 7,300 from India. ${ }^{59}$ As shown in Table 5 below, immigrants from Canada have a naturalization rate of 61 percent, and immigrants from India have a rate of 78 percent.

Examination of the complete list of metro areas showed that Arizona, California, and Texas had the largest numbers of cities with relatively low naturalization rates. Table 5 shows naturalization rates for these three states as well as rates for the cities with the largest eligible-to-naturalize populations. Four cities in California had especially low naturalization rates - Salinas (52 percent), Visalia-Porterville (56 percent), Bakersfield (57 percent), and Fresno (58 percent). In Texas, the lowest rates were for the McAllen area (53 percent), Laredo (54 percent), and Brownsville-Harlingen (58 percent).

All the metro areas shown in Table 5 had naturalization rates below the national average of 74 percent except for four metro areas in California: San Diego (76 percent), San Jose (77 percent), Sacramento (77 percent), and San Francisco (78 percent). Of these three states, the largest number eligible to naturalize, 900,000, live in the Los Angeles area (Table 5).

Table 6 shows naturalization rates for relatively smaller areas (those with 20,000 to 65,000 eligible to naturalize) and excludes metro areas in the states shown in Table 5. These metro areas, scattered across the country, generally have naturalization rates near or above the national average of 74 percent. Only Milwaukee (64 percent), Indianapolis (65 percent), Oklahoma City (68 percent), and Raleigh (68 percent) have naturalization rates lower than 71 percent.

Table 7 shows naturalization rates for countries that have 50,000 or more eligible to naturalize. Nearly 2.5 million, or 31 percent of the total, are from Mexico. Except for Japan (47 percent), immigrants from Mexico have the lowest naturalization rate (60 percent). Other countries with below-average naturalization rates include Canada (61 percent), United Kingdom (63 percent), and the three Northern Triangle countries, Honduras (62 percent), Guatemala (67 percent), and El Salvador (67 percent). Immigrants from five Asian countries have above-average naturalization rates: China (75 percent), India (78 percent), Korea (82 percent), Philippines (85 percent), and Vietnam (88 percent) (Table 7). Five other countries also have relatively high naturalization rates: Haiti (78 percent), Italy (80 percent), Colombia (82 percent), Jamaica (84 percent), and Poland (84 percent).

59 Detailed eligible-to-naturalization data are available on the CMS website at http://data.cmsny.org/puma.html. Estimates shown in this report might differ slightly from those shown on the website because of rounding. 
Table 6. Naturalization Rates for Metro Areas with 20,000 to 65,000 Eligible to Naturalize, Excluding AZ, CA, and TX Metro Areas: 2019

Numbers in thousands.

Ranked by percent naturalized (column 4)

Metropolitan area Naturalized Eligible to naturalize Legal foreign-born Percent naturalized

\begin{tabular}{|c|c|c|c|c|}
\hline & (1) & (2) & $(3)=(1)+(2)$ & $(4)=(1) /(3)$ \\
\hline US Total & 23,095 & 8,102 & 31,197 & $74 \%$ \\
\hline Milwaukee-Waukesha-West Allis, WI & 48 & 27 & 75 & $64 \%$ \\
\hline Indianapolis-Carmel-Anderson, IN & 61 & 33 & 94 & $65 \%$ \\
\hline Oklahoma City, OK & 48 & 23 & 70 & $68 \%$ \\
\hline Raleigh, NC & 72 & 34 & 106 & $68 \%$ \\
\hline Salt Lake City, UT & 62 & 25 & 87 & $71 \%$ \\
\hline Nashville-Davidson-Murfreesboro-Franklin, TN & 73 & 29 & 102 & $71 \%$ \\
\hline Naples-Immokalee-Marco Island, FL & 53 & 20 & 73 & $72 \%$ \\
\hline Charlotte-Concord-Gastonia, NC-SC & 114 & 41 & 155 & $73 \%$ \\
\hline Bridgeport-Stamford-Norwalk, CT & 108 & 39 & 146 & $74 \%$ \\
\hline Cape Coral-Fort Myers, FL & 71 & 25 & 96 & $74 \%$ \\
\hline Denver-Aurora-Lakewood, CO & 184 & 65 & 249 & $74 \%$ \\
\hline Kansas City, MO-KS & 68 & 24 & 92 & $74 \%$ \\
\hline Worcester, MA-CT & 64 & 22 & 86 & $74 \%$ \\
\hline Jacksonville, FL & 85 & 27 & 112 & $76 \%$ \\
\hline Portland-Vancouver-Hillsboro, OR-WA & 170 & 51 & 220 & $77 \%$ \\
\hline Columbus, $\mathrm{OH}$ & 94 & 28 & 122 & $77 \%$ \\
\hline Providence-Warwick, RI-MA & 132 & 39 & 172 & $77 \%$ \\
\hline Baltimore-Columbia-Towson, MD & 161 & 48 & 208 & $77 \%$ \\
\hline Urban Honolulu, $\mathrm{HI}$ & 120 & 35 & 155 & $78 \%$ \\
\hline Hartford-West Hartford-East Hartford, CT & 95 & 26 & 121 & $78 \%$ \\
\hline St. Louis, MO-IL & 73 & 20 & 93 & $79 \%$ \\
\hline Cleveland-Elyria, $\mathrm{OH}$ & 75 & 20 & 95 & $79 \%$ \\
\hline Detroit-Warren-Dearborn, MI & 250 & 62 & 313 & $80 \%$ \\
\hline Minneapolis-St. Paul-Bloomington, MN-WI & 235 & 54 & 289 & $81 \%$ \\
\hline
\end{tabular}

Source: Center for Migration Studies. See text for methods of estimation. 
Table 7. Naturalization Rates for Countries with 50,000 or More Eligible-to-Naturalize in 2019.

Numbers in thousands.

Ranked by percent naturalized (column 4)

Country of birth

Naturalized

Eligible to naturalize

Legal foreign-born

Percent naturalized

\begin{tabular}{|c|c|c|c|c|}
\hline & (1) & (2) & $(3)=(1)+(2)$ & $(4)=(1) /(3)$ \\
\hline US Total & 23,095 & 8,102 & 31,197 & $74 \%$ \\
\hline Japan & 115 & 132 & 247 & $47 \%$ \\
\hline Mexico & 3,694 & 2,490 & 6,184 & $60 \%$ \\
\hline Canada & 401 & 257 & 658 & $61 \%$ \\
\hline Honduras & 167 & 101 & 268 & $62 \%$ \\
\hline United Kingdom & 376 & 223 & 599 & $63 \%$ \\
\hline Guatemala & 305 & 153 & 458 & $67 \%$ \\
\hline El Salvador & 482 & 242 & 724 & $67 \%$ \\
\hline Brazil & 172 & 70 & 242 & $71 \%$ \\
\hline Germany & 350 & 135 & 485 & $72 \%$ \\
\hline Dominican Republic & 666 & 242 & 908 & $73 \%$ \\
\hline Ecuador & 229 & 86 & 315 & $73 \%$ \\
\hline Cuba & 829 & 312 & 1,141 & $73 \%$ \\
\hline Peru & 257 & 85 & 343 & $75 \%$ \\
\hline Iraq & 150 & 50 & 200 & $75 \%$ \\
\hline China & 1,315 & 443 & 1,758 & $75 \%$ \\
\hline Haiti & 442 & 122 & 564 & $78 \%$ \\
\hline India & 1,254 & 350 & 1,604 & $78 \%$ \\
\hline Italy & 230 & 56 & 286 & $80 \%$ \\
\hline Colombia & 496 & 105 & 602 & $82 \%$ \\
\hline Korea & 684 & 147 & 831 & $82 \%$ \\
\hline Jamaica & 536 & 102 & 638 & $84 \%$ \\
\hline Poland & 299 & 59 & 358 & $84 \%$ \\
\hline Philippines & 1,460 & 253 & 1,714 & $85 \%$ \\
\hline Vietnam & 1,049 & 144 & 1,193 & $88 \%$ \\
\hline
\end{tabular}

Source: Center for Migration Studies. See text for methods of estimation. 


\section{Changes in Naturalization Rates for Selected Countries from 2010 to 2019}

Figure 1 shows the percentage of legal residents who were naturalized after residing in the United States an average of 10 years. The dark gray bars are for 2010, and the light bars are for 2019. In 2010, about 60 percent of legal immigrants from India that had resided in the United States an average of 10 years had naturalized. In 2019, the comparable figure was 48 percent. In other words, keeping average duration of residence constant (at 10 years), the percent naturalized from India dropped from 60 percent to 48 percent from 2010 to 2019 (Figure 1). The comparable rate for China dropped from 58 percent to 50 percent. Changes for Central America and Mexico were in the opposite direction: the rate for Central America increased from 39 percent to 55 percent, and the rate for Mexico increased from 35 percent to 48 percent (Figure 1).

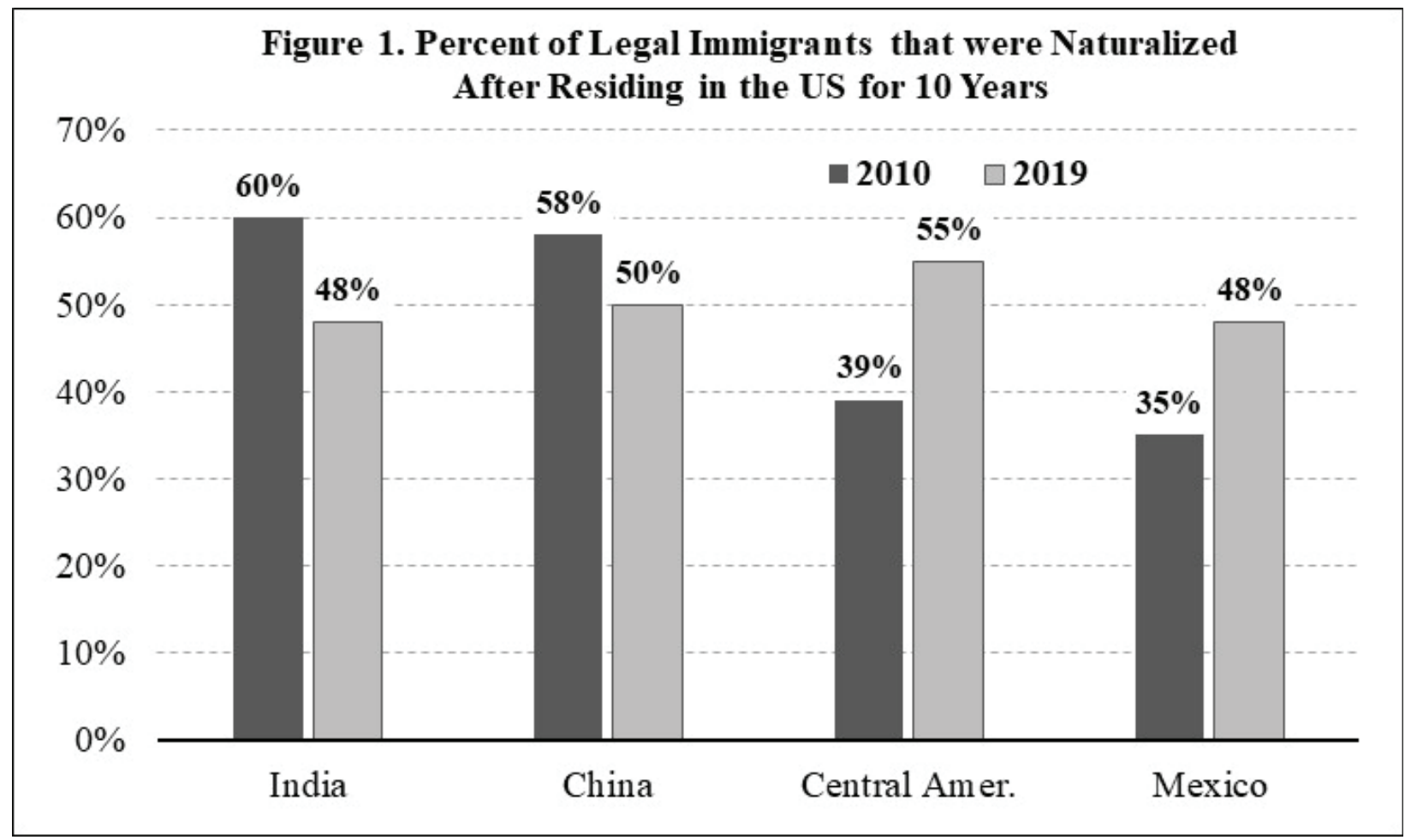

The data shown in Figure 1 seems to indicate a significant shift in patterns of naturalization for these countries. Historically, naturalization rates were considerably higher for India and China than they were for Central America and Mexico. For example, in 2019, naturalization rates for immigrants that had resided in the US an average of 25 years were: India, 94 percent; China, 86 percent; Central America, 65 percent; and Mexico, 52 percent. The 10-year rate of 48 percent for Mexico in 2019 is only four percentage points lower than the 25-year rate for Mexico in 2019. In other words, in 2019 the naturalization rate for immigrants from Mexico that had resided here an average of 10 years was almost as high as the rate for immigrants from Mexico that had resided here for 25 years. 


\section{Policy Recommendations}

This paper proposes that the United States should treat naturalization not as the potential culmination of a long, uncertain, individual process, but as an organizing goal of the US immigration system and an expectation for new Americans. It posits immigrants as would-be citizens in a tolerant, pluralistic nation rooted in the core ideals of equality, justice, freedom, opportunity, and the rule of law, and it urges the Biden-Harris administration to craft its immigration, naturalization, and integration policies accordingly.

\section{"The United States should treat naturalization not as the culmination of a long and uncertain individual process, but as an organizing principle of the US immigration system and its expectation for new Americans."}

To further this vision, the paper identifies administrative actions and, to a lesser degree, legislative proposals that would expand access to permanent residence and citizenship. It also analyzes three underlying factors - financial resources, English language proficiency, and education - that strongly influence naturalization rates, that must be a national priority for new Americans, and mostly cannot be addressed in the context of the naturalization process. Finally, it offers detailed estimates of populations with large eligible-to-naturalize numbers, populations that naturalize at low rates, and populations with increasing naturalization rates. In doing so, it provides a roadmap on how to expand the pool of eligible-to-naturalize noncitizens and the factors and populations that should be prioritized to increase naturalization numbers and rates.

The paper endorses the US Citizenship Act of 2021, 60 particularly its provisions that would place undocumented and temporary residents on a path to permanent residence and citizenship, would reduce family- and employment-based visa backlogs, and would eliminate disincentives and barriers to permanent residence, such as the three- and 10-year bars on admission. It also supports the Biden-Harris administration's early executive actions to broaden access to permanent residency and naturalization, such as its actions to:

- Reverse the previous administration's public charge rule.

- Eliminate travel bans from select Muslim-majority and African countries, as well as the bans justified as being necessary to economic recovery.

- Re-designate, designate, and extend Temporary Protected Status and Deferred Enforced Departure to select national groups.

- Restore the Central American Minors program.

- Adopt meaningful immigration enforcement and prosecutorial discretion standards and encourage immigrants to apply for immigration benefits.

The paper also supports the Biden-Harris administration's commitment to improve and expedite the naturalization process. It proposes that DHS and DOS strengthen current guidance on the

60 US Citizenship Act of 2021. HR 1177 and S. 348, 117 th Cong. (2021). 
public charge grounds of inadmissibility by specifying the federal benefits considered in public charge determinations, how far back adjudicators will look regarding receipt of benefits, and how far in the future they will look to gauge if an applicant is likely to become a public charge. In addition, it proposes that DHS:

- Clarify that a legally sufficient affidavit of support will satisfy the public charge test in most cases.

- Issue regulations to expand the DACA program by updating the eligibility guidelines related to age at entry (from 16- to 18-years old), continuous residence (from June 15, 2007 to June 15, 2016) and physical presence in the United States (from June 15, 2012 to January 1, 2021).

- Allow applicants to apply for DACA who were prevented from doing so by the prior administration's cancellation of the program.

- Relax the eligibility requirement for advance parole and confirm that DACA and TPS recipients that return to the United States with advance parole are considered "inspected and admitted or paroled" for the purposes of adjusting status.

- Redesignate and provide new designations of TPS to the countries devastated by Hurricanes Eta and lota in late 2020.

- Grant an 18-month extension and redesignation of TPS for Yemen, Somalia, and South Sudan, and consider designating several additional African countries for TPS, including Mauritania, Cameroon, Guinea, and Sierra Leone.

- Extend the December 2021 deadline for filing for permanent residence under the Liberian Refugee and Immigration Fairness program.

- Clarify that departure and return on advance parole does not execute an outstanding removal order, thus permitting TPS recipients who are the immediate relatives of US citizens to adjust status with USCIS and, as part of this process, waive the removal ground of inadmissibility.

- Overturn an Administrative Appeals Office decision in Matter of Z-R-Z-C-, Adopted Decision 2020-02 (AAO Aug. 20, 2020).

- Change USCIS policy, via a policy memorandum and settling a lawsuit, that departure and return on advance parole does not execute an outstanding removal order, thus allowing TPS recipients who are immediate relatives of US citizens to file for adjustment of status with USCIS, and (with a Form I-212) to waive the removal order ground of inadmissibility.

- Reduce application processing delays by prioritizing the adjudication of family-based petitions and applications, ending "extreme vetting" and unnecessary investigations, restoring the InfoPass customer service system, and reinstating the policy requiring adjudicators to issue a Request of Evidence or Notice of Intent to Deny before denying a petition or application. 
The paper recommends that the Biden-Harris administration pursue a broad-based, horizontally integrated, public-private naturalization strategy that prioritizes populations with large numbers of eligible-to-naturalize immigrants, those with low naturalization rates, and those with increasing naturalization rates, as set forth in the paper. These estimates should also inform the citizenship and immigrant integration programs of states, localities, employers, and community-based agencies.

Beyond the naturalization process itself, the paper argues that the administration's naturalization strategy must address the major determinants of naturalization, particularly financial resources, English proficiency, and education, starting well before immigrants seek to naturalize. It proposes that the Biden-Harris and subsequent administrations treat new Americans as would be US citizens and prepare them to naturalize and to integrate fully from their earliest days in the country.

"The Biden-Harris administration should pursue a broad-based, horizontally integrated, public-private naturalization strategy that prioritizes populations with large numbers of eligible-to-naturalize immigrants, those with low naturalization rates, those with increasing naturalization rates."

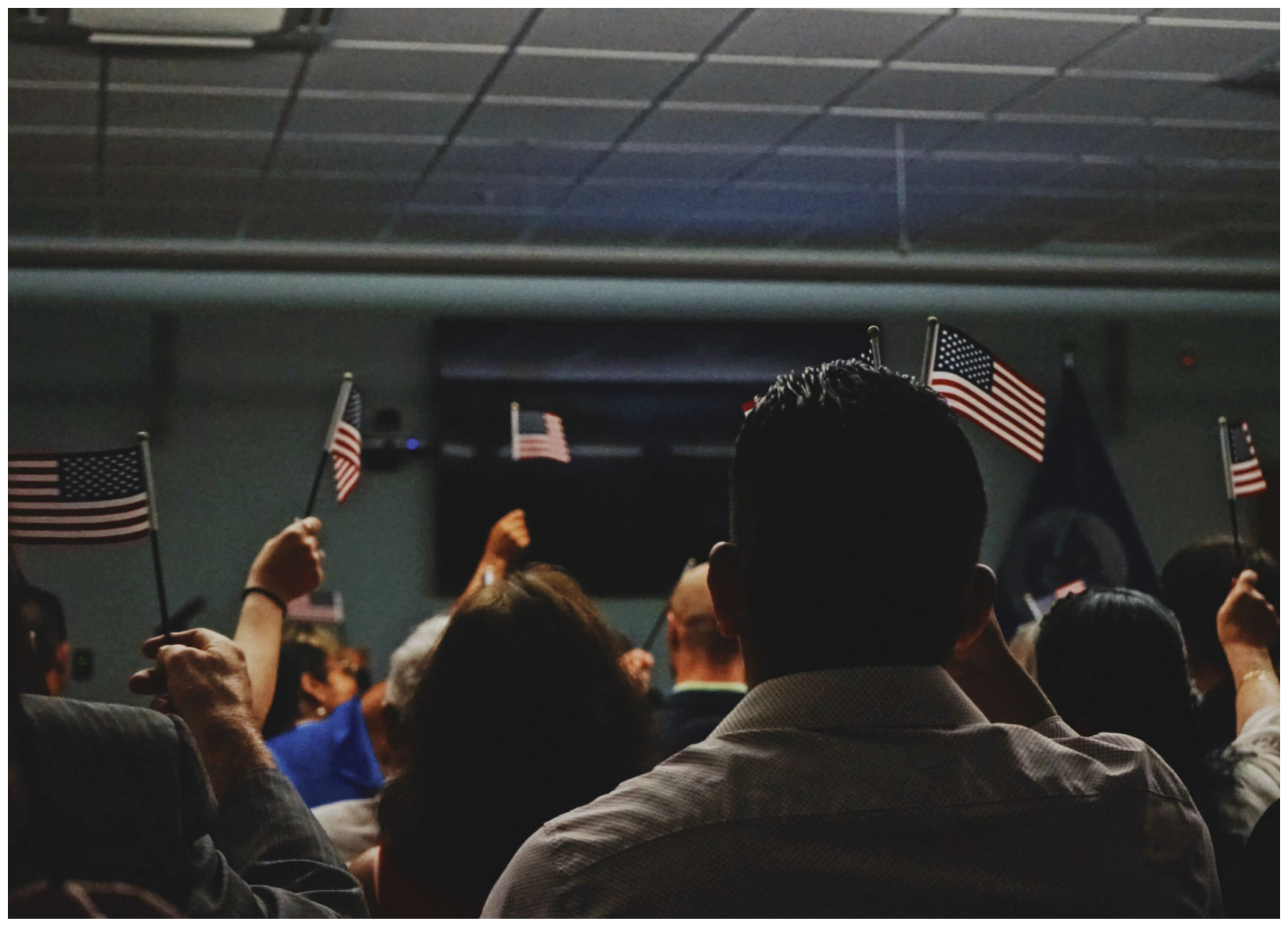




\section{References}

Aleinikoff, T. Alexander and Donald Kerwin. 2021. "Improving the US Immigration System in the First Year of the Biden Administration." New York: Center for Migration Studies of New York and Zolberg Institute on Migration and Mobility. https://cmsny.org/publications/ immigration-recommendations-biden/

Anderson, Stuart. 2021. "The Story of How Trump Officials Tried to End H-1B Visas." Forbes, February 1. https://www.forbes.com/sites/stuartanderson/2021/02/01/the-story-of-howtrump-officials-tried-to-end-h-1b-visas/?sh=3ccf9127173f

2020. "Trump's Immigration Policy Now Blocks World's Most Highly Skilled." Forbes, August 12. https://www.forbes.com/sites/stuartanderson/2020/08/12/trump-immigrationpolicy-now-blocks-worlds-most-highly-skilled/?sh=7b2b69dd40a9

Bean, Frank D., Susan K. Brown, and James D. Bachmeier. 2015. Parents Without Papers: The Progress and Pitfalls of Mexican American Integration. New York: Russell Sage Foundation.

Bernstein, Hamutal, Dulce Gonzalez, Michael Karpman, and Stephen Zuckerman. 2020. "Amid Confusion Over the Public Charge Rule, Immigrant Families Continued Avoiding Immigrant Benefits in 2016." Washington, DC: Urban Institute. https://www.urban. org/sites/default/files/publication/102221/amid-confusion-over-the-public-charge-ruleimmigrant-families-continued-avoiding-public-benefits-in-2019 3.pdf

Biden-Harris Campaign. 2020. "The Biden Plan for Securing Our Values as a Nation of Immigrants." https://joebiden.com/immigration/

CMS (Center for Migration Studies of New York). 2021. "President Biden's Executive Actions on Immigration." New York: CMS. https://cmsny.org/biden-immigration-executive-actions/

Chishti, Muzaffar and Jessica Bolter. 2020. "The Trump Effect on Legal Immigration Levels: More Perception than Reality?" Washington, DC: Migration Policy Institute. https://www. migrationpolicy.org/article/trump-effect-immigration-reality

Collins, Laura. 2021. "Citizenship Matters: Encouraging Immigrants to Become Americans." Dallas, TX: George W. Bush Institute. https://www.bushcenter.org/publications/ resources-reports/reports/immigration-white-papers/citizenship-matters-encouragingimmigrants-to-become-americans.html 
De Graauw, Els and Irene Bloemraad. 2017. "Working Together: Building Successful Policy and Program Partnerships for Immigrant Integration." Journal on Migration and Human Security 5(1): 105-123. https://journals.sagepub.com/doi/10.1177/233150241700500106

DOS (US Department of State). 2020. "Annual Report of Immigrant Visa Applicants in the Familysponsored and Employment-based preferences Registered at the National Visa Center as of November 1, 2020." Washington, DC: DOS.https://travel.state.gov/content/dam/ visas/Statistics/Immigrant-Statistics/WaitingList/WaitingListltem 2020 vF.pdf

Foer, Franklin. 2018. "How Trump Radicalized ICE." The Atlantic. https://www.theatlantic.com/ magazine/archive/2018/09/trump-ice/565772/

Guttentag, Lucas. 2021. "Immigration Policy Tracking Project." https://immpolicytracking.org/ home/

INS (Immigration and Naturalization Service). 1999. "Public Charge: INA Sections 212(a)(4) and 237(a)(5)." Memorandum from Michael A. Pearson, Executive Associate Commissioner, Office of Field Operations, to all Regional Directors, May 20. Washington, DC: USCIS.

Kerwin, Donald. 2010. "More than IRCA: US Legalization Programs and the Current Policy Debate." MPI Policy Brief. Washington, DC: Migration Policy Institute. https://www. migrationpolicy.org/pubs/legalization-historical.pdf

Kerwin, Donald and Mike Nicholson. 2021. "Charting a Course to Rebuild and Strengthen the US Refugee Admissions Program (USRAP): Findings and Recommendations from the Center for Migration Studies Refugee Resettlement Survey - 2020." Journal on Migration and Human Security 9(1): 1-30. https://journals.sagepub.com/doi/ full/10.1177/2331502420985043

Kerwin, Donald and Robert Warren. 2019a. "Putting Americans First: A Statistical Case for Encouraging Rather than Impeding and Devaluing US Citizenship." Journal on Migration and Human Security 7(4): 108-122. https://journals.sagepub.com/doi/ full/10.1177/2331502419894286

2019b. "Fixing What's Most Broken in the US Immigration System: A Profile of the Family Members of US Citizens and Lawful Permanent Residents Mired in Multiyear Backlogs." Journal on Migration and Human Security 7(2): 36-41. https://journals.sagepub.com/ doi/full/10.1177/2331502419852925

Kraut, Alan. 2016. "Nativism, An American Perennial." CMS Essays. New York: Center for Migration Studies. https://doi.org/10.14240/cmsesy020816 
Lynch, Robert and Patrick Oakford. 2013. "The Economic Effects of Granting Legal Status and Citizenship to Undocumented Immigrants." Washington, DC: Center for American Progress. https://www.americanprogress.org/issues/immigration/reports/2013/03/20/57351/ the-economic-effects-of-granting-legal-status-and-citizenship-to-undocumentedimmigrants/

Martin, Susan F. 2021. A Nation of Immigrants. $2^{\text {nd }}$ ed. New York: Cambridge University Press.

2020. "Rebuilding the US Refugee Resettlement Program." CMS Essays. New York: Center for Migration Studies. https://cmsny.org/publications/rebuilding-the-us-refugeeresettlement-program/

Miroff, Nick and Josh Dawsey. 2019. "The Adviser Who Scripts Trump's Immigration Policy." The Washington Post, August 17. https://www.washingtonpost.com/graphics/2019/ politics/stephen-miller-trump-immigration/.

Motomura, Hiroshi. 2006. Americans in Waiting: The Lost Story of Immigration and Citizenship in the United States. New York: Oxford University Press.

NAS (National Academies of Science, Engineering, and Medicine). 2015. The Integration of Immigrants into American Society, edited by Mary C. Waters and Marisa Gerstein Pineau, Panel on the Integration of Immigrants into American Society, and Committee on Population, Division of Behavioral and Social Sciences and Education. Washington, DC: The National Academies Press. https://doi.org/10.17226/21746.

Nowrasteh, Alex. 2021. "President Trump Reduced Legal Immigration. He Did Not Reduce Illegal Immigration." Washington, DC: Cato Institute. https://www.cato.org/blog/ president-trump-reduced-legal-immigration-he-did-not-reduce-illegal-immigration

Pierce, Sarah and Jessica Bolter. 2020. "Dismantling and Reconstructing the US Immigration System: A Catalog of Changes under the Trump Presidency." Washington, DC: Migration Policy Institute. https://www.migrationpolicy.org/research/us-immigration-systemchanges-trump-presidency.

Rosenberg, Mica. 2017. "US ends program for Central American minors fleeing violence." Reuters, August 16. https://www.reuters.com/article/us-usa-immigration-minors/u-sends-program-for-central-american-minors-fleeing-violence-idUSKCN1AW2OZ.

Ryo, Emily and lan Peacock. 2019. "Denying Citizenship: Immigration Enforcement and Citizenship Rights in the United States." Center for Law and Social Science Research Papers Series No. CLASS19-31, USC Law Legal Studies Paper No. 19-31. Los Angeles: University of Southern California Gould School of Law. https://www.researchgate. net/publication/336242314 Denying Citizenship Immigration Enforcement and Citizenship Rights in the United States. 
Svailenka, Nicole. 2020. "Protecting Undocumented Workers on the Pandemic's Front Lines: Immigrants are Essential to America's Recovery." Washington, DC: Center for American Progress. https://www.americanprogress.org/issues/immigration/ reports/2020/12/02/493307/protecting-undocumented-workers-pandemics-front-lines/

Sacchetti, Maria and Arelis R. Hernández. 2021. "To lead ICE, Biden Picks Texas sheriff who criticized Trump's immigration policies." Washington Post, April 27. https://www. washingtonpost.com/immigration/ed-gonzalez-ice/2021/04/27/3c25c7c6-a785-11ebbca5-048b2759a489 story.html

Schoenholtz, Andrew I., Jaya Ramji-Nogales, and Philip G. Schrag. 2021. The End of Asylum. Washington, DC: Georgetown University Press.

USCIS (US Citizenship and Immigration Services). 2021a. "Historical National Median Processing Time (in Months) for All USCIS Offices for Select Forms by Fiscal Year." Washington, DC: USCIS. https://egov.uscis.gov/processing-times/historic-pt

. 2021b. Policy Manual. Washington, DC: USCIS. https://www.uscis.gov/policy-manual

2020. "Number of Form N-400, Application for Naturalization: By Category of Naturalization, Case Status, and USCIS Field Office Location, April 1 - June 30, 2020." Washington, DC: USCIS. https://www.uscis.gov/sites/default/files/document/reports/ N400 performancedata fy2020 qtr3.pdf

Warren, Robert. 2021. "In 2019, the US Undocumented Population Continued a DecadeLong Decline and the Foreign-Born Population Neared Zero Growth." Journal on Migration and Human Security 9(1):31-43. https://journals.sagepub.com/ doi/10.1177/2311502421993746

Warren, Robert and Donald Kerwin. 2017. "A Statistical and Demographic Profile of US Temporary Protected Status Populations from El Salvador, Honduras, and Haiti." Journal on Migration and Human Security 5(3): 577-592. https://journals.sagepub.com/ doi/10.1177/233150241700500302

- 2015. "The US Eligible-to-Naturalize Population: Detailed Social and Economic Characteristics." Journal on Migration and Human Security 3(4): 306-329. https:// journals.sagepub.com/doi/pdf/10.1177/233150241500300401

Wheeler, Charles. 2019. "Backlogs in Family-Based Immigration: Shedding Light on the Numbers." Washington, DC: Catholic Immigration Network, Inc. https://cliniclegal.org/ resources/family-based-immigrant-law/backlogs-family-based-immigration-sheddinglight-numbers 
2014. "The Evolution of United States Immigration Laws." In International Migration, US Immigration Law and Civil Society: From the Colonial Era to the 113th Congress, edited by Leonir Chiarello and Donald Kerwin. New York: Scalabrini International Migration Network. $\quad$ https://cmsny.org/publications/simn-cms-intllmigration-usimmigrationlawcivilsociety/

White House Task Force on New Americans. 2015a. "Strengthening Communities by Welcoming All Residents: A Federal Strategic Plan on Immigrant \& Refugee Integration," April. https://obamawhitehouse.archives.gov/sites/default/files/docs/final tf newamericans report 4-14-15 clean.pdf

. 2015b. "We can make every American feel welcome -and make our communities stronger in the process." https://obamawhitehouse.archives.gov/issues/immigration/ new-americans

Young, Julia G. 2017. "Making America 1920 Again? Nativism and US Immigration, Past and Present." Journal on Migration and Human Security 5(1): 217-235. https://journals. sagepub.com/doi/pdf/10.1177/233150241700500111 